\title{
An Aluminum Dihydride Working as a Catalyst in Hydroboration and Dehydrocoupling
}

\author{
Zhi Yang, ${ }^{, \dagger}$ Mingdong Zhong, ${ }^{\dagger}$ Xiaoli Ma, ${ }^{\dagger}$ Karikkeeriyil Nijesh, ${ }^{\#}$ \\ Susmita De, ${ }^{\#}$ Pattiyil Parameswaran, ${ }^{*, \#}$ and Herbert W. Roesky ${ }^{*, \star}$ \\ †School of Chemical Engineering and Environment, Beijing Institute of Technology, \\ 100081 Beijing, China \\ IInstitut für Anorganische Chemie der Georg-August-Universität Göttingen, \\ Tammannstrasse 4, D-37077 Göttingen, Germany \\ \# Department of Chemistry, National Institute of Technology Calicut, NIT Campus \\ P.O., Kozhikhode 673601 Kerala, India.
}

\section{Table of Contents}

Synthesis of Aluminum Dihydride Complex 1

S2

Single crystal X-ray structure and refinement

S3

Experimental Section

S5

NMR spectra of products from organoboration

S11

Computational Details

S24

References

S31 
General considerations: All manipulations were carried out under a purified nitrogen atmosphere using Schlenk techniques or inside aMbraun MB200 glove box. All solvents were distilled from $\mathrm{Na} /$ benzophenoneketyl prior to use. PhCCD was prepared according to the literature. ${ }^{[1]}$ Commercially available chemicals were purchased from J\&K chemical or VAS and used as received. ${ }^{1} \mathrm{H}$ and ${ }^{13} \mathrm{C}$ NMR spectra were recorded with a Varian Mercury Plus 400 MHz or Bruker Avance III 600 MHz spectrometer. CCDC-1436306 (1) contains the supplementary crystallographic data for this paper. This data can be obtained free of charge from The Cambridge Crystallographic Data Centre via www.ccdc.cam.ac.uk/data_request/cif.
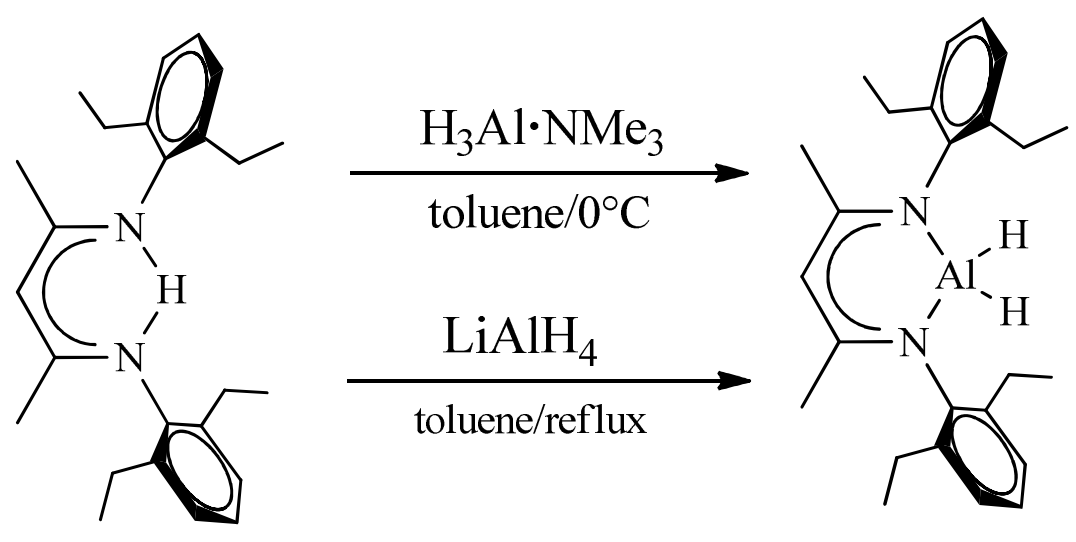

Scheme S1. Synthesis of Aluminum Dihydride Complex 1 


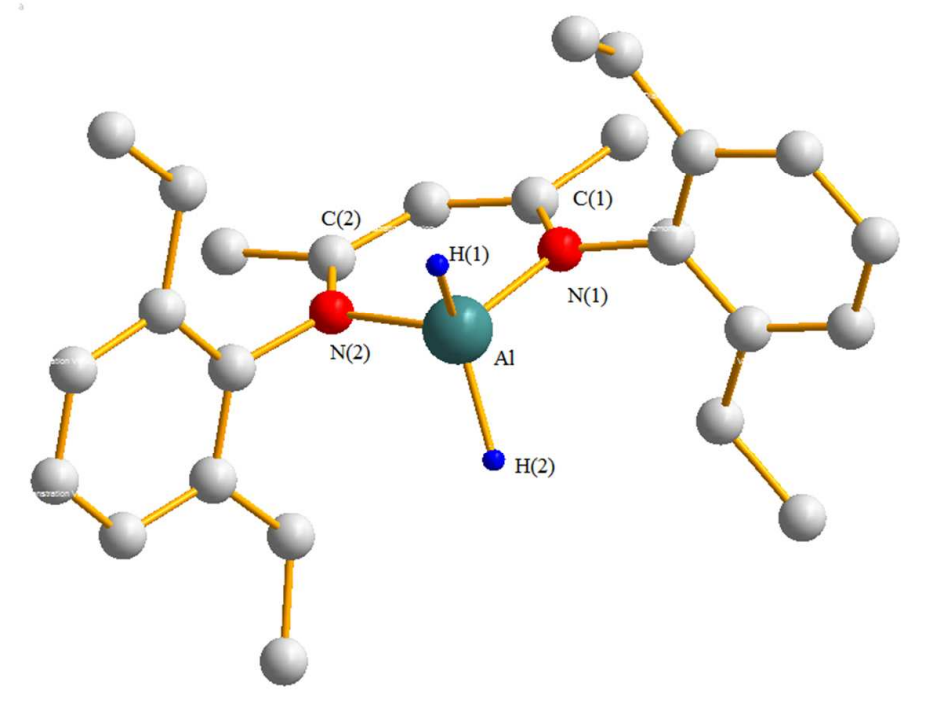

Figure S1. Molecular structure of $\mathbf{1}$. Thermal ellipsoids are drawn at the $50 \%$ level and the hydrogen atoms are omitted for clarity except those at the aluminum. Selected bond distances $(\AA)$ and angles (deg): Al-N(1) 1.8883(10), $\quad \mathrm{N}(1)-\mathrm{C}(1) \quad 1.3294(15), \quad \mathrm{N}(2)-\mathrm{Al}(1)-\mathrm{N}(1) \quad 96.60(6)$, $\mathrm{C}(2)-\mathrm{N}(2)-\mathrm{Al125.01(8),} \mathrm{C(1)-N(1)-A1113.17(7)}$

A single crystal of $\mathbf{1}$ was mounted with glue on a glass fiber and crystal data were collected on the Rigaku AFC10 Saturn $724+(2 \times 2$ bin mode $)$ diffractometer equipped with graphite-monochromated Mo K $\alpha$ radiation $(\lambda=0.71073 \AA)$. Empirical absorption correction was applied using the SADABS program. ${ }^{2}$ The structure was solved by direct methods ${ }^{3}$ and refined by full-matrix least squares on $\mathrm{F}^{2}$ using the SHELXL-97 program. ${ }^{4}$ A summary of the crystal data is given in Table S1. 


\begin{tabular}{|c|c|}
\hline $\begin{array}{r}\text { TableS1 } \\
\end{array}$ & 1 \\
\hline Empirical formula & $\mathrm{C}_{25} \mathrm{H}_{35} \mathrm{Al} \mathrm{N} \mathrm{N}_{2}$ \\
\hline Formula weight & 390.53 \\
\hline Temperature (K) & $153(2)$ \\
\hline Wavelength $(\AA ̊)$ & 0.71073 \\
\hline Crystal system & Monoclinic \\
\hline Space group & $C 2 / c$ \\
\hline $\mathrm{a}(\AA)$ & $15.382(4)$ \\
\hline b $(\AA)$ & $7.1655(18)$ \\
\hline $\mathrm{c}(\AA)$ & $21.607(6)$ \\
\hline$\alpha\left(^{\circ}\right)$ & 90 \\
\hline$\beta\left({ }^{\circ}\right)$ & $90.107(3)$ \\
\hline$\gamma\left({ }^{\circ}\right)$ & 90 \\
\hline $\mathrm{V}\left(\AA^{3}\right)$ & $2381.5(10)$ \\
\hline $\mathrm{Z}$ & 4 \\
\hline Dcalcd. $\left(\mathrm{Mg} / \mathrm{m}^{3}\right)$ & 1.089 \\
\hline Absorption coefficient $\left(\mathrm{mm}^{-1}\right)$ & 0.097 \\
\hline $\mathrm{F}(000)$ & 848 \\
\hline \multirow[t]{3}{*}{$\theta$ range for data collection $\left(^{\circ}\right)$} & 2.55 to 31.49 \\
\hline & $-22 \leq h \leq 22$ \\
\hline & $-10 \leq k \leq 10$ \\
\hline Index ranges & $-31 \leq l \leq 31$ \\
\hline Reflections collected & 14512 \\
\hline R (int) & 0.0248 \\
\hline Data / restraints / parameters & $3933 / 2 / 155$ \\
\hline Goodness-of-fit on $F^{2}$ & 1.002 \\
\hline \multirow[t]{2}{*}{ Final Rint $[I>2 \sigma(I)]$} & $R 1=0.0659$ \\
\hline & $w R 2=0.1597$ \\
\hline \multirow[t]{2}{*}{ Rint (all data) } & $R 1=0.0563$ \\
\hline & $w R 2=0.1494$ \\
\hline Largest diff. peak $\left[\mathrm{e} \AA^{-3}\right]$ & 0.322 and -0.199 \\
\hline
\end{tabular}


Method I for preparation of $\mathbf{L A l H}_{2}$ : A solution of $\mathrm{LH}(\mathrm{L}=$ $\left.\mathrm{HC}(\mathrm{CMeNAr})_{2}, \mathrm{Ar}=2,6-\mathrm{Et}_{2} \mathrm{C}_{6} \mathrm{H}_{3}\right)(2.16 \mathrm{~g}, 5.98 \mathrm{mmol})$ in toluene $(40 \mathrm{~mL})$ was added at room temperature to a solution of $\mathrm{AlH}_{3} \cdot \mathrm{NMe}_{3}(0.56 \mathrm{~g}, 6.29$ $\mathrm{mmol})$ in toluene $(10 \mathrm{~mL})$, and the resulting mixture was stirred for $48 \mathrm{~h}$. All volatile components were removed in vacuo, and the crude product was crystallized from $n$-hexane to afford colorless crystals of 1 (1.93 g, yield $89 \%$ based on LH); m.p. $163{ }^{\circ} \mathrm{C}{ }^{1} \mathrm{H}$ NMR (400 MHz, $\left.\mathrm{CDCl}_{3}\right): \delta$ 7.18-7.28 (m, 6H, aromatic of Ar group), $5.09(\mathrm{~s}, 1 \mathrm{H}, \gamma-\mathrm{CH}), 2.75,2.60$ (sept, 4H, $\mathrm{CH}_{2} \mathrm{Me}$ ), 1.69 (s, 6H, CMe $), 1.25$ (trip, $12 \mathrm{H}, \mathrm{CH}_{2} \mathrm{Me}$ ); ${ }^{13} \mathrm{C}$ NMR (100 MHz, $\left.\mathrm{CDCl}_{3}\right): \delta 169.95(\mathrm{CN}), 140.91,139.07,126.57,126.14$ (Ar), $96.13(\gamma-\mathrm{CH}), 23.66\left(\mathrm{CH}_{2} \mathrm{Me}\right), 22.65\left(\mathrm{CH}_{2} \mathrm{Me}\right), 14.13(\mathrm{Me}) . \mathrm{IR}$ $\left(\mathrm{KBr}, \mathrm{cm}^{-1}\right): v=1540,1790 \mathrm{~cm}^{-1}(\mathrm{~m}, \mathrm{Al}-\mathrm{H})$.

Method II for preparation of $\mathbf{L A l H}_{2}$ : To a mixture of $\mathrm{LH}(2.16 \mathrm{~g}, 5.98$ mmol $)$ and a little excess of $\mathrm{LiAlH}_{4}(0.23 \mathrm{~g}, 7 \mathrm{mmol})$ was added toluene $(50 \mathrm{~mL})$. The suspension was stirred and heated at $110{ }^{\circ} \mathrm{C}$ for $12 \mathrm{~h}$. After cooling to room temperature, the suspension was filtered to remove the insoluble residue and the filtrate was evaporated to dryness to yield a colorless crystalline solid of $\mathrm{LAlH}_{2}$ in almost quantitative yield (based on LH).

The stoichiometric reaction of 1 with $\mathrm{PhCCH}(1: 1)$ was performed at room temperature for $6 \mathrm{~h}$, solvents and excess $\mathrm{PhCCH}$ were removed in 
vacuo at $40{ }^{\circ} \mathrm{C}$ to result in a solid containing a mixture of products.
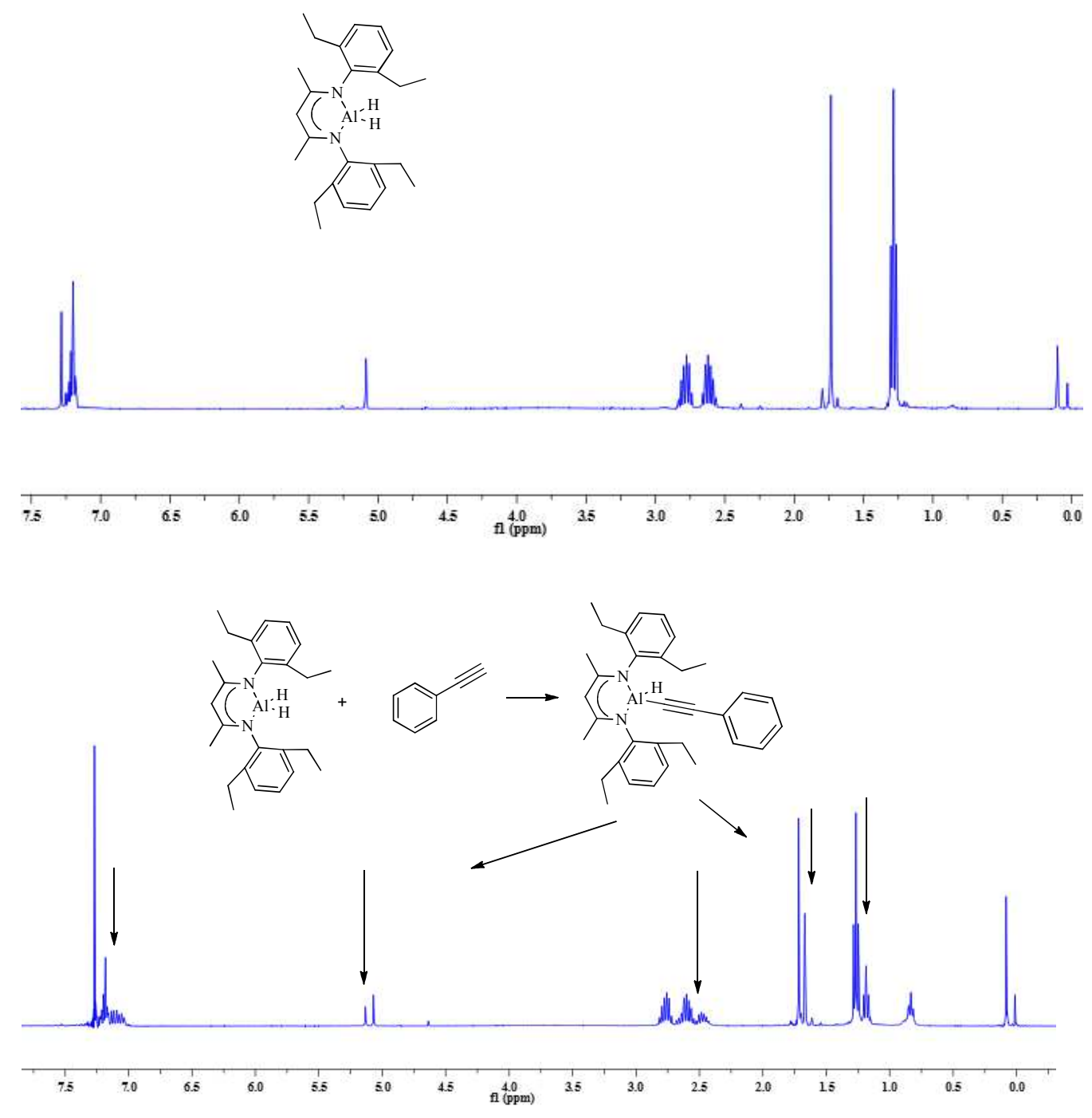

Scheme S2. ${ }^{1} \mathrm{H}$ NMR (400 MHz, $\left.\mathrm{CDCl}_{3}, 23{ }^{\circ} \mathrm{C}\right)$. Top spectrum, starting material of $\mathbf{1}$, bottom spectrum of the crude product from the reaction of $\mathrm{LAlH}_{2}$ with $\mathrm{PhCCH}$. 

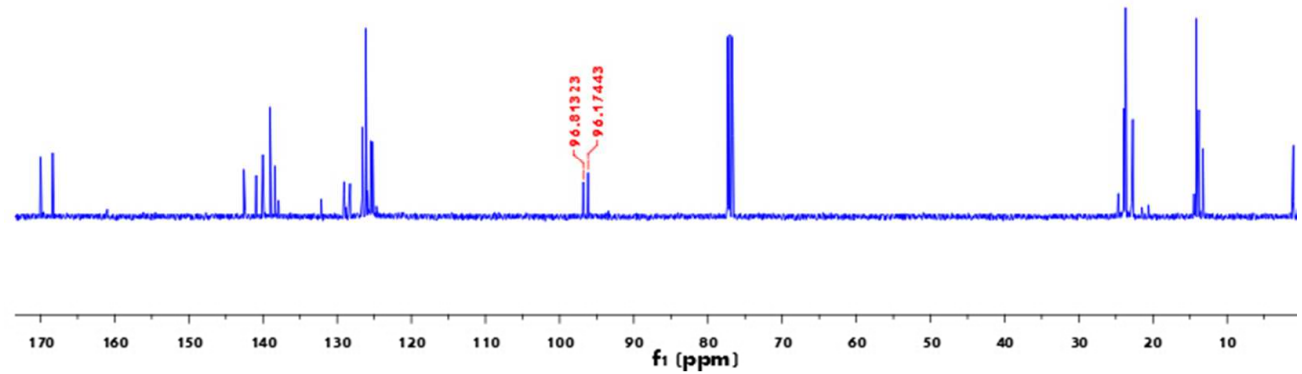

Scheme S3. ${ }^{13} \mathrm{C}$ NMR $\left(400 \mathrm{MHz}, \mathrm{CDCl}_{3}, 23{ }^{\circ} \mathrm{C}\right)$ of the crude product from the reaction of $\mathrm{LAlH}_{2}$ with $\mathrm{PhCCH}$.

The stoichiometric reaction of 1 with $\mathrm{C}_{6} \mathrm{H}_{4} \mathrm{FOH}$ (1:1) was accomlished at room temperature for $6 \mathrm{~h}$, solvents were removed in vacuo to result in a solid containing a mixture of products.

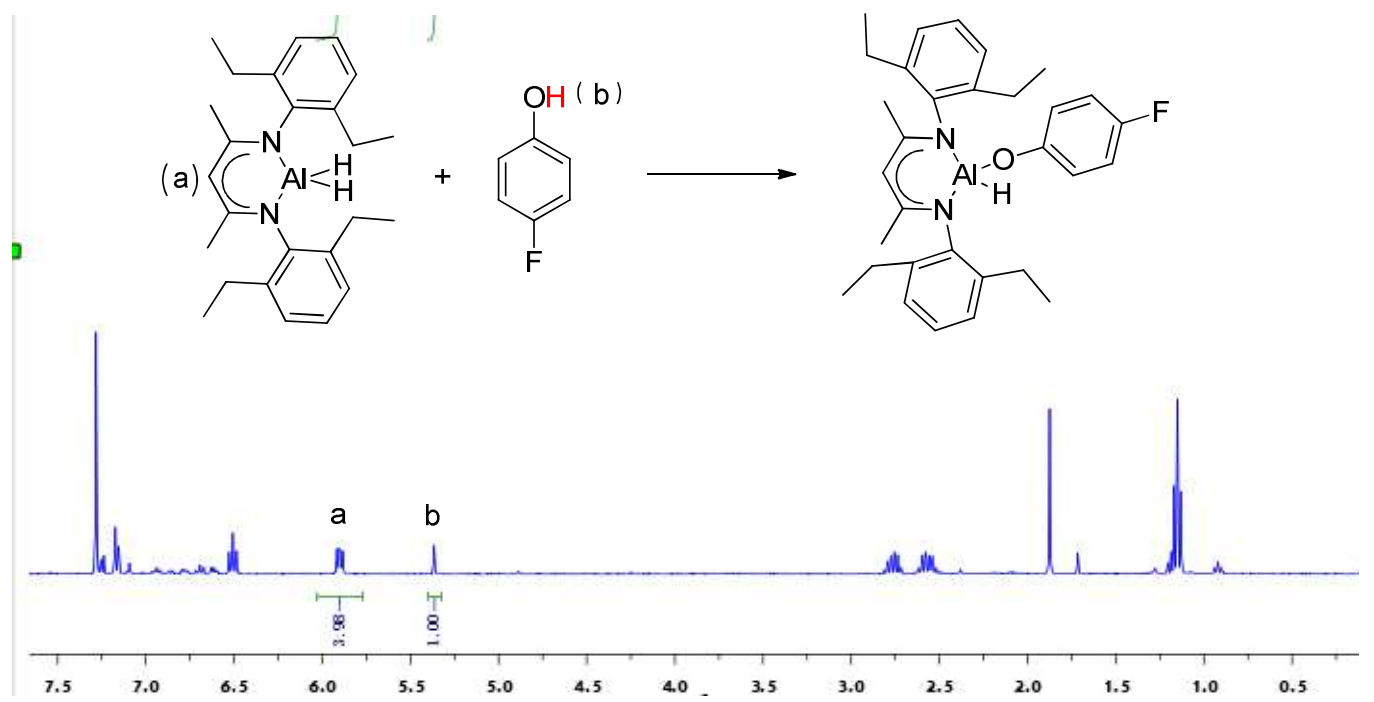




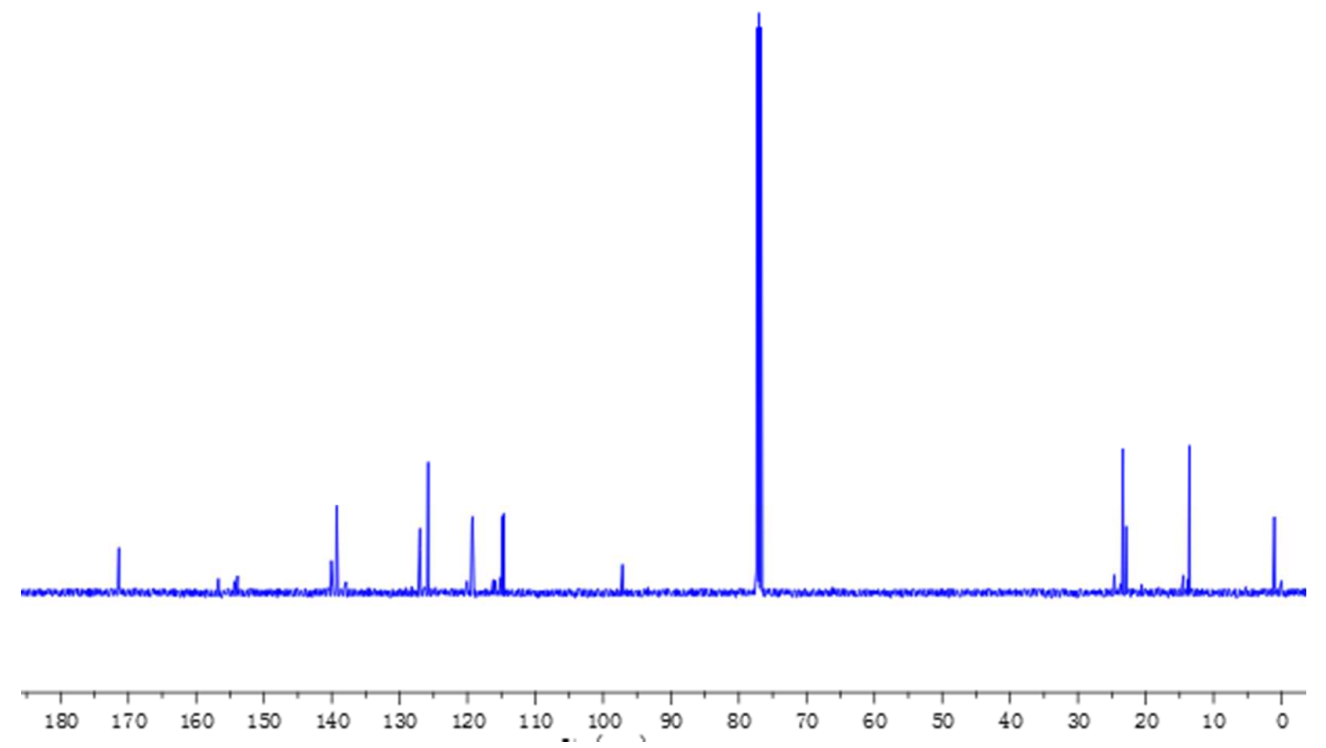

Scheme S4. ${ }^{1} \mathrm{H}$ (top) and ${ }^{13} \mathrm{C}$ NMR (bottom) $\left(\mathrm{CDCl}_{3}, 23{ }^{\circ} \mathrm{C}\right)$ of the crude product from the reaction of $\mathrm{LAlH}_{2}$ with $\mathrm{C}_{6} \mathrm{H}_{4} \mathrm{FOH}$. 
The stoichiometric reaction of $\mathbf{1}$ with $\mathrm{HBPin}$ at room temperature. no noticeable reaction was observed between $\mathrm{LAlH}_{2}$ and $\mathrm{HBPin}$, as evidenced by the characteristic low field hydride resonance $\left({ }^{1} \mathrm{H}\right.$ NMR) of 1, which shifted negligibly upon addition of HBPin to the solution.

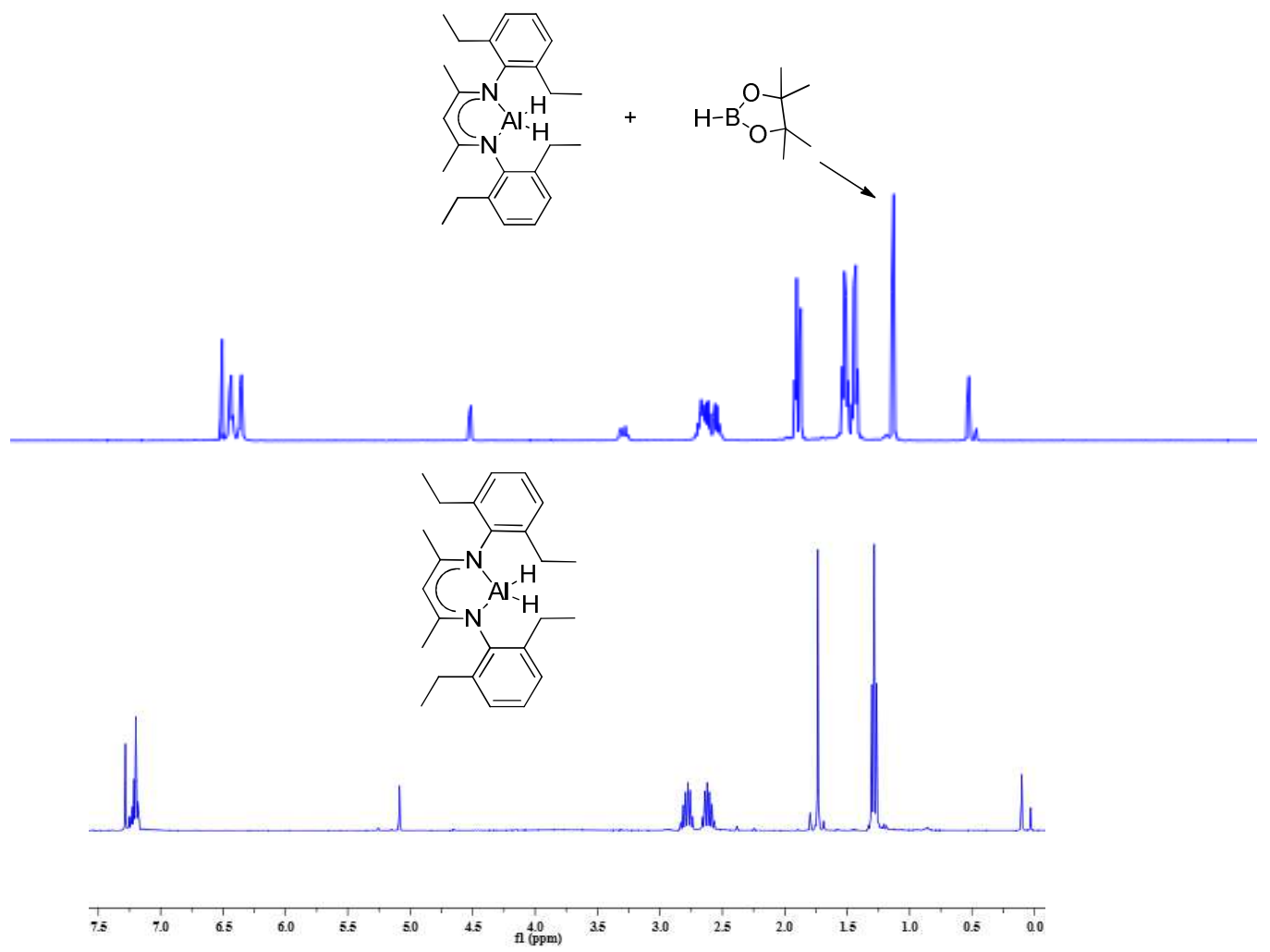

Scheme S5. ${ }^{1} \mathrm{H}$ NMR (400 MHz, $\mathrm{CDCl}_{3}, 23{ }^{\circ} \mathrm{C}$ ). Top spectrum of the crude product from the reaction of $\mathrm{LAlH}_{2}$ with HBPin. Bottom spectrum, starting material of $\mathbf{1}$. 


\section{Preparation of PhCHCD(BPin)}

Compound 1 (0.05 mmol), PhCCD (1.2 mmol), HBPin (0.15 mL, $1 \mathrm{mmol})$ and $\mathrm{CDCl}_{3}(1 \mathrm{~mL})$ were loaded in a dried J-Young Tube under nitrogen atmosphere. The tube was sealed, shaken at $30{ }^{\circ} \mathrm{C}$ and the progress of the reaction was followed by ${ }^{1} \mathrm{H}$ NMR spectroscopy.

The reaction of 1.2 equiv of $\mathrm{PhCCD}$ with HBPin yielded the $(E)$ isomer with the deuterium in the geminal position to the [BPin] substituent. The reaction was carried out within $32 \mathrm{~h}$. The deuterium label did not scramble into the $\alpha$-position of the vinylboronate.

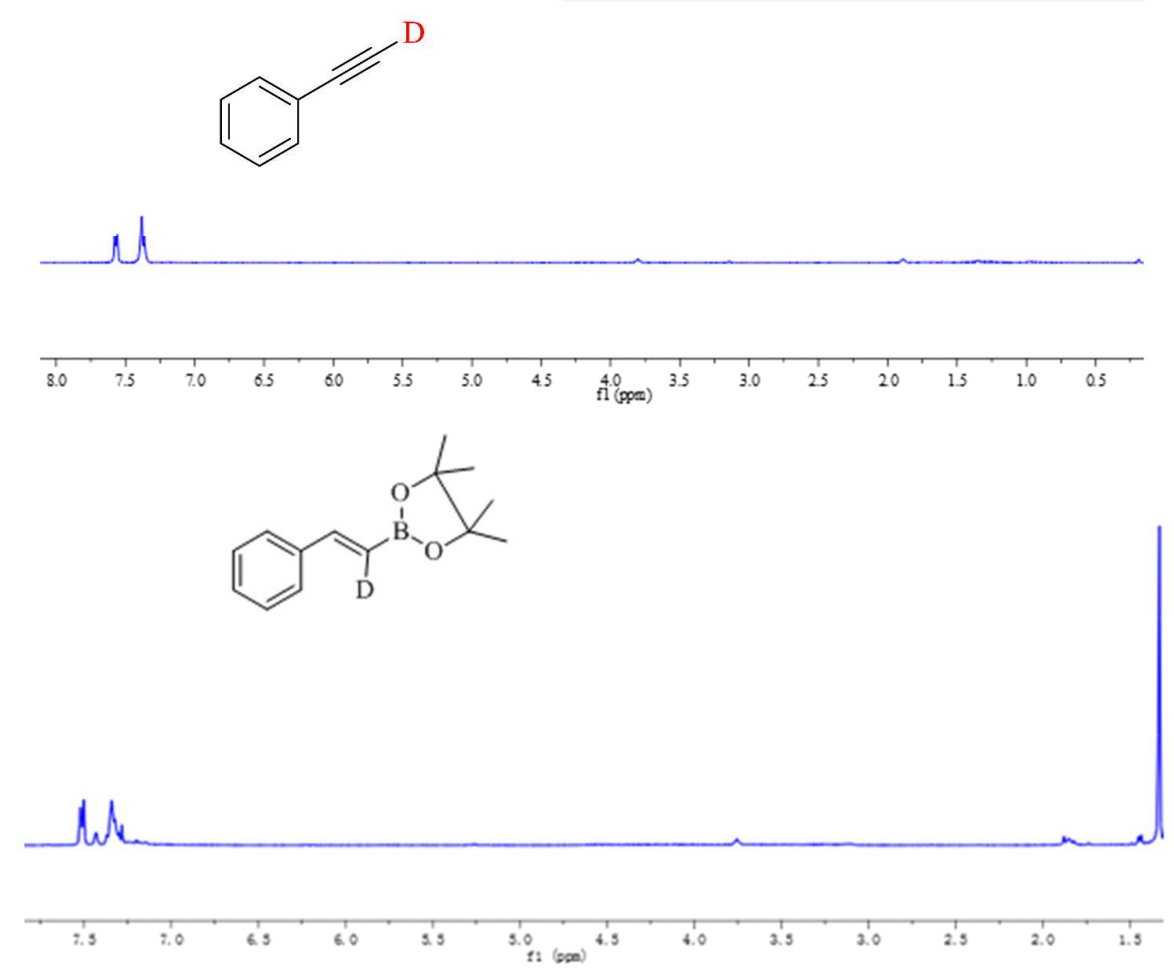

Scheme S6. ${ }^{1} \mathrm{H}$ NMR $\left(400 \mathrm{MHz}, \mathrm{CDCl}_{3}, 23^{\circ} \mathrm{C}\right)$. Top spectrum of $\mathrm{PhCCD}$, bottom spectrum of $\mathrm{PhCHCD(BPin).}$ 


\section{Catalytic NMR experiments}

The relevant amounts of dry substrates, catalyst and deuterated solvent were directly added to a Young NMR tube under inert atmosphere. All liquids were added with Eppendorf pipettes. A homogenous solution was obtained by moving the tube several times upside down. Phenol-, thiol-, and aminoboranes were synthesized according to conditions noted in the caption of Scheme 3. Alkynes react with boranes under the same conditions shown in the caption of Scheme 1 , however at $30{ }^{\circ} \mathrm{C}$.

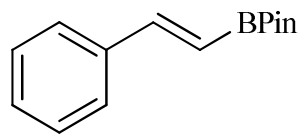

${ }^{1} \mathrm{H}$ NMR $\left(600 \mathrm{MHz}, \mathrm{CDCl}_{3}, 23{ }^{\circ} \mathrm{C}\right) \delta 1.31(\mathrm{~s}, 12 \mathrm{H}, \mathrm{Me})$, $6.21(\mathrm{~d}, 1 \mathrm{H}, \mathrm{CH}), 7.44(\mathrm{~d}, 1 \mathrm{H}, \mathrm{CH}), 7.31-7.52(\mathrm{~m}, 5 \mathrm{H}, \mathrm{Ar}-) ;{ }^{13} \mathrm{C} \mathrm{NMR}$ $\left(150 \mathrm{MHz}, \mathrm{CDCl}_{3}, 23{ }^{\circ} \mathrm{C}\right) \delta 24.83,83.30,126.57,128.55,137.15$, 149.39.Purification by silica gel chromatography (gradient elution, 1-5\% EtOAc in hexanes).

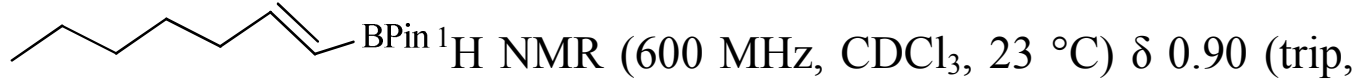
$3 \mathrm{H}, \mathrm{Me}), 1.29(\mathrm{~s}, 12 \mathrm{H}, \mathrm{Me}), 1.29\left(\mathrm{~m}, 2 \mathrm{H}, \mathrm{CH}_{2}\right), 1.41\left(\mathrm{~m}, 2 \mathrm{H}, \mathrm{CH}_{2}\right), 2.17$ $(\mathrm{m}, 2 \mathrm{H}, \mathrm{CH}), 5.44(\mathrm{~d}, 1 \mathrm{H}, \mathrm{CH}), 6.65(\mathrm{~d}, 1 \mathrm{H}, \mathrm{CH}) ;{ }^{13} \mathrm{C}$ NMR $(150$ $\left.\mathrm{MHz}, \mathrm{CDCl}_{3}, 23^{\circ} \mathrm{C}\right) \delta 13.69,22.32,24.19,27.79,31.31,35.60,82.77$, 154.77. Purification by silica gel chromatography (gradient elution, $1-5 \%$ EtOAc in hexanes). 


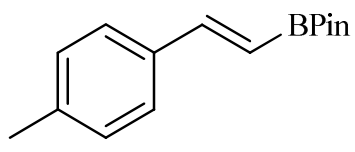

${ }^{1} \mathrm{H}$ NMR $\left(600 \mathrm{MHz}, \mathrm{CDCl}_{3}, 23{ }^{\circ} \mathrm{C}\right) \delta 1.34(\mathrm{~s}, 12 \mathrm{H}$, $M e), 2.37(\mathrm{~s}, 3 \mathrm{H}, M e), 6.15(\mathrm{~d}, 1 \mathrm{H}, \mathrm{CH}), 7.16(\mathrm{~d}, 1 \mathrm{H}, \mathrm{CH}), 7.38-7.42(\mathrm{~m}$, $4 \mathrm{H}, \mathrm{Ar}-) ;{ }^{13} \mathrm{C}$ NMR $\left(150 \mathrm{MHz}, \mathrm{CDCl}_{3}, 23{ }^{\circ} \mathrm{C}\right) \delta 21.26,24.82,83.29$, $127.02,127.05,129.38,131.82,138.91,149.17$. Purification by silica gel chromatography (gradient elution, 1-5\% EtOAc in hexanes).

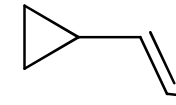

BPin ${ }^{1} \mathrm{H}$ NMR $\left(600 \mathrm{MHz}, \mathrm{CDCl}_{3}, 23^{\circ} \mathrm{C}\right) \delta 0.56\left(\mathrm{~m}, 2 \mathrm{H}, \mathrm{CH}_{2}\right)$, $0.82\left(\mathrm{~m}, 2 \mathrm{H}, \mathrm{CH}_{2}\right), 1.28(\mathrm{~s}, 12 \mathrm{H}, \mathrm{Me}), 1.63(\mathrm{~m}, 1 \mathrm{H}, \mathrm{CH}), 5.50(\mathrm{~d}, 1 \mathrm{H}$, $\mathrm{CH}), 6.09(\mathrm{~d}, 1 \mathrm{H}, \mathrm{CH}) ;{ }^{13} \mathrm{C} \mathrm{NMR}\left(150 \mathrm{MHz}, \mathrm{CDCl}_{3}, 23{ }^{\circ} \mathrm{C}\right) \delta 7.99,16.96$, $24.79,82.77,158.17$. Purification by silica gel chromatography (gradient elution, 1-5\% EtOAc in hexanes).

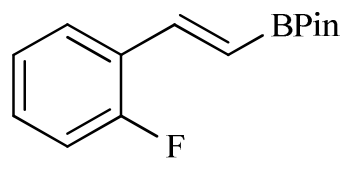

${ }^{1} \mathrm{H}$ NMR $\left(600 \mathrm{MHz}, \mathrm{CDCl}_{3}, 23{ }^{\circ} \mathrm{C}\right) \delta 1.31(\mathrm{~s}, 12 \mathrm{H}$, $M e), 6.17(\mathrm{~d}, 1 \mathrm{H}, \mathrm{CH}), 7.19(\mathrm{~d}, 1 \mathrm{H}, \mathrm{CH}), 7.26-7.38(\mathrm{~m}, 4 \mathrm{H}, \mathrm{Ar}-) ;{ }^{13} \mathrm{C}$ $\operatorname{NMR}\left(150 \mathrm{MHz}, \mathrm{CDCl}_{3}, 23^{\circ} \mathrm{C}\right) \delta=24.83,83.30,113.35,115.72,123.05$, $129.68,139.63,147.73,162.05,164.00$. Purification by silica gel chromatography (gradient elution, 1-5\% EtOAc in hexanes).

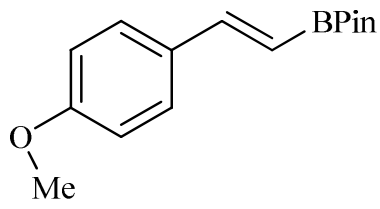

${ }^{1} \mathrm{H}$ NMR $\left(600 \mathrm{MHz}, \mathrm{CDCl}_{3}, 23^{\circ} \mathrm{C}\right) \delta=1.31(\mathrm{~s}, 12 \mathrm{H}$, $M e), 3.81$ (s, $3 \mathrm{H}, M e), 5.97(\mathrm{~d}, 1 \mathrm{H}, \mathrm{CH}), 7.37(\mathrm{~d}, 1 \mathrm{H}, \mathrm{CH}), 6.87(\mathrm{~m}, 2 \mathrm{H}$, $\mathrm{Ar}-), 7.43(\mathrm{~m}, 2 \mathrm{H}, \mathrm{Ar}-) .{ }^{13} \mathrm{C} \mathrm{NMR}\left(150 \mathrm{MHz}, \mathrm{CDCl}_{3}, 23^{\circ} \mathrm{C}\right) \delta=24.81$, 
$55.39,82.99,113.90,128.23,130.11,149.05,160.18$. Purification by silica gel chromatography (gradient elution, 1-5\% EtOAc in hexanes).

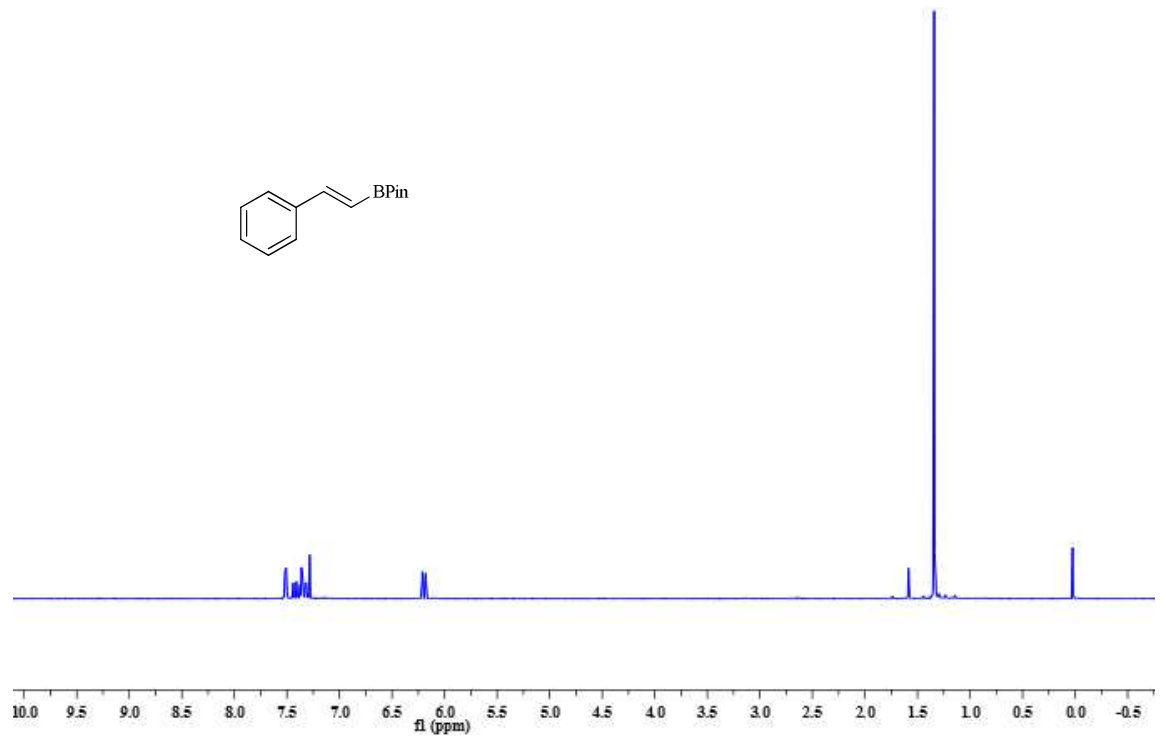




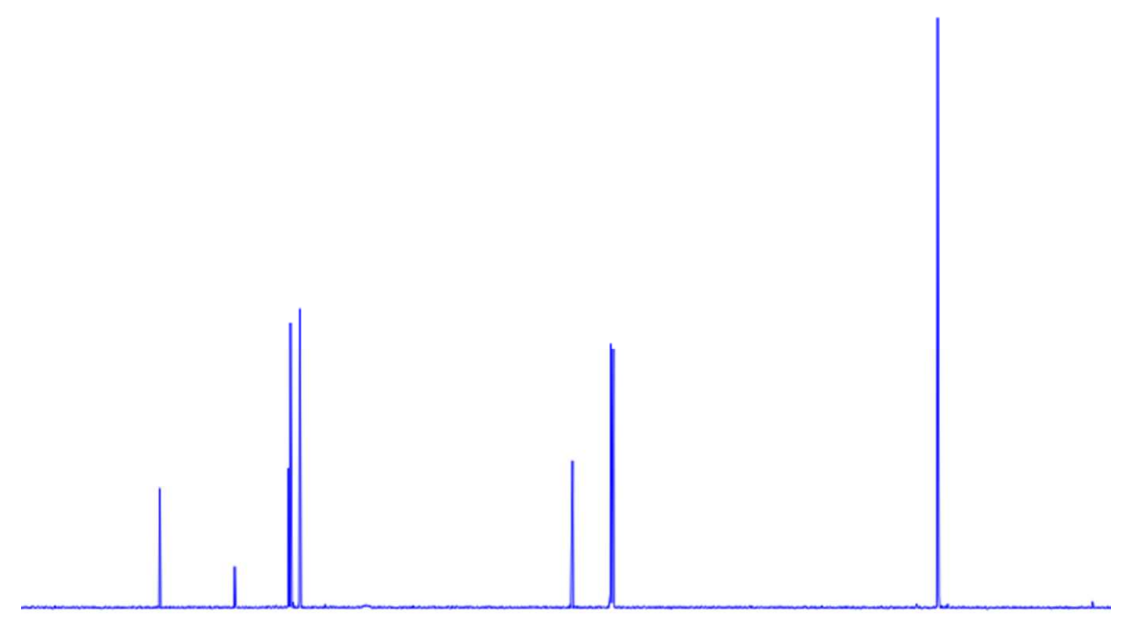

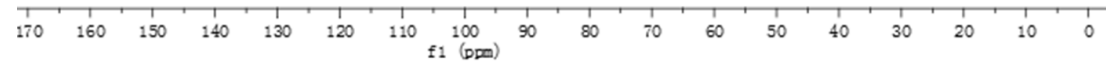

Scheme S7. ${ }^{1} \mathrm{H}$ (top) and ${ }^{13} \mathrm{C}$ NMR (bottom) $\left(\mathrm{CDCl}_{3}, 23{ }^{\circ} \mathrm{C}\right)$ of product 1 of Scheme 1.
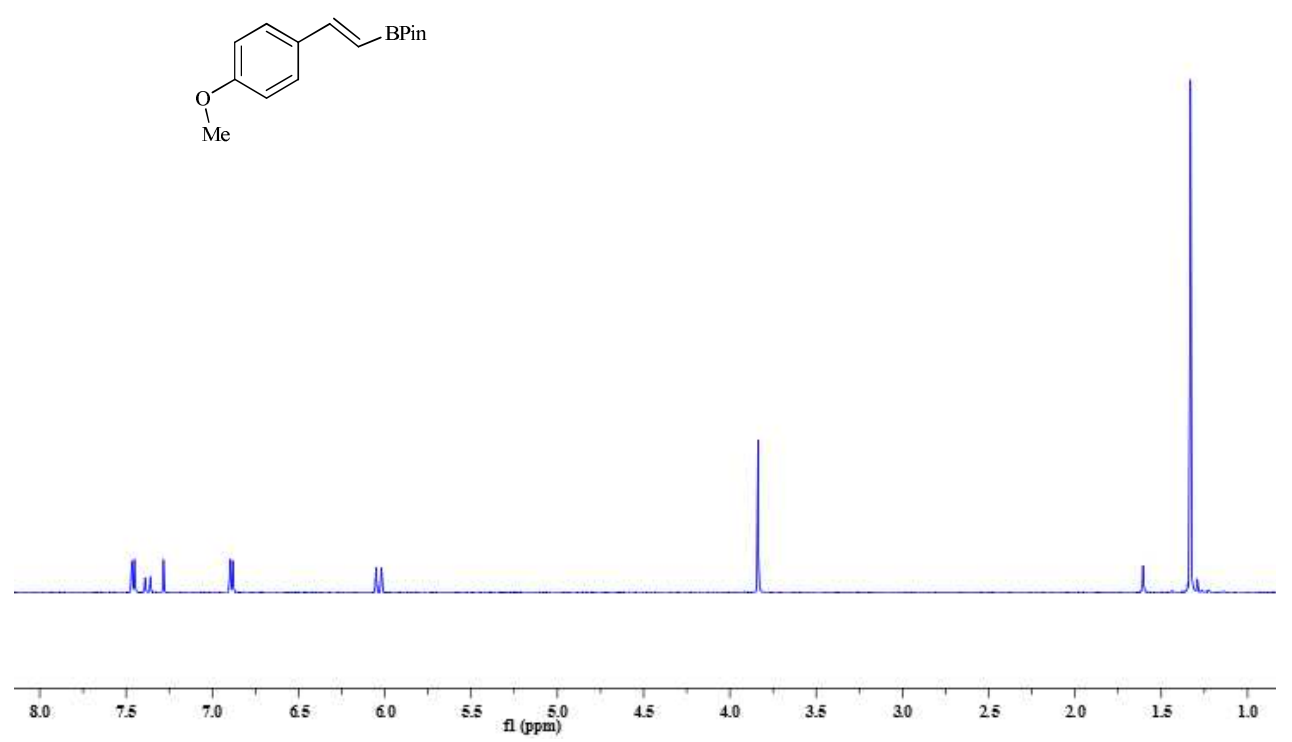

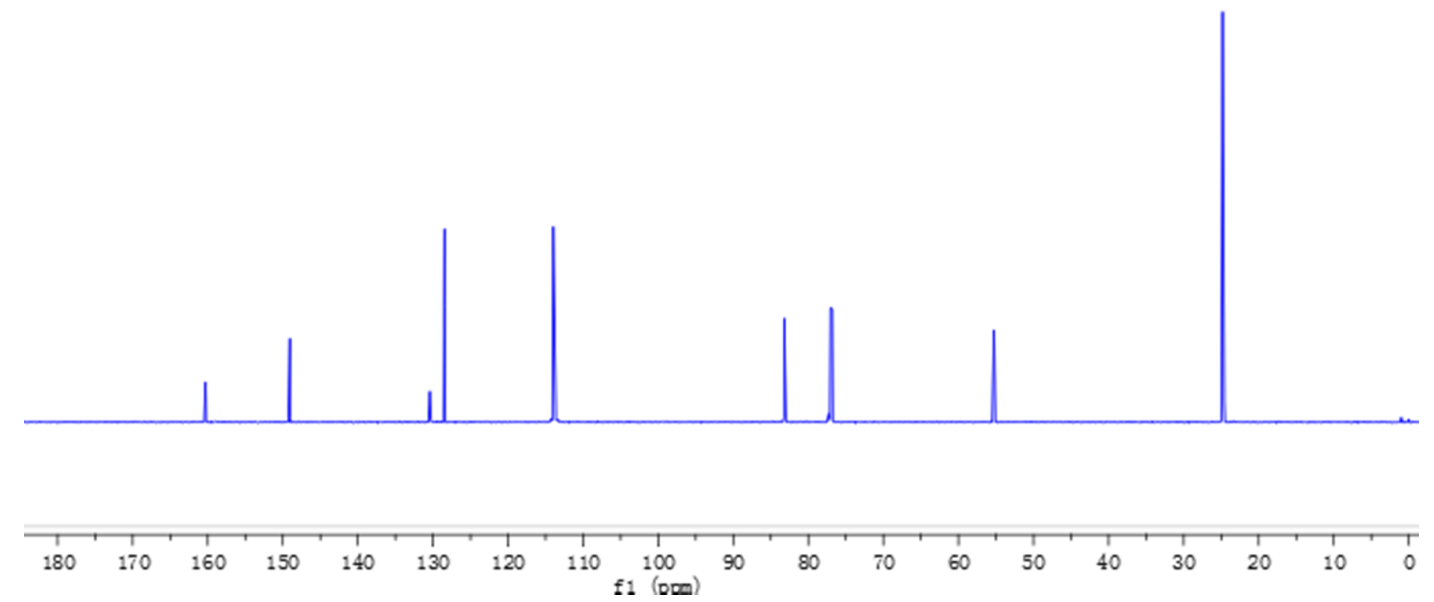

Scheme S8. ${ }^{1} \mathrm{H}$ (top) and ${ }^{13} \mathrm{C}$ NMR (bottom) spectra $\left(\mathrm{CDCl}_{3}, 23{ }^{\circ} \mathrm{C}\right)$ of product 2 of Scheme 1. 

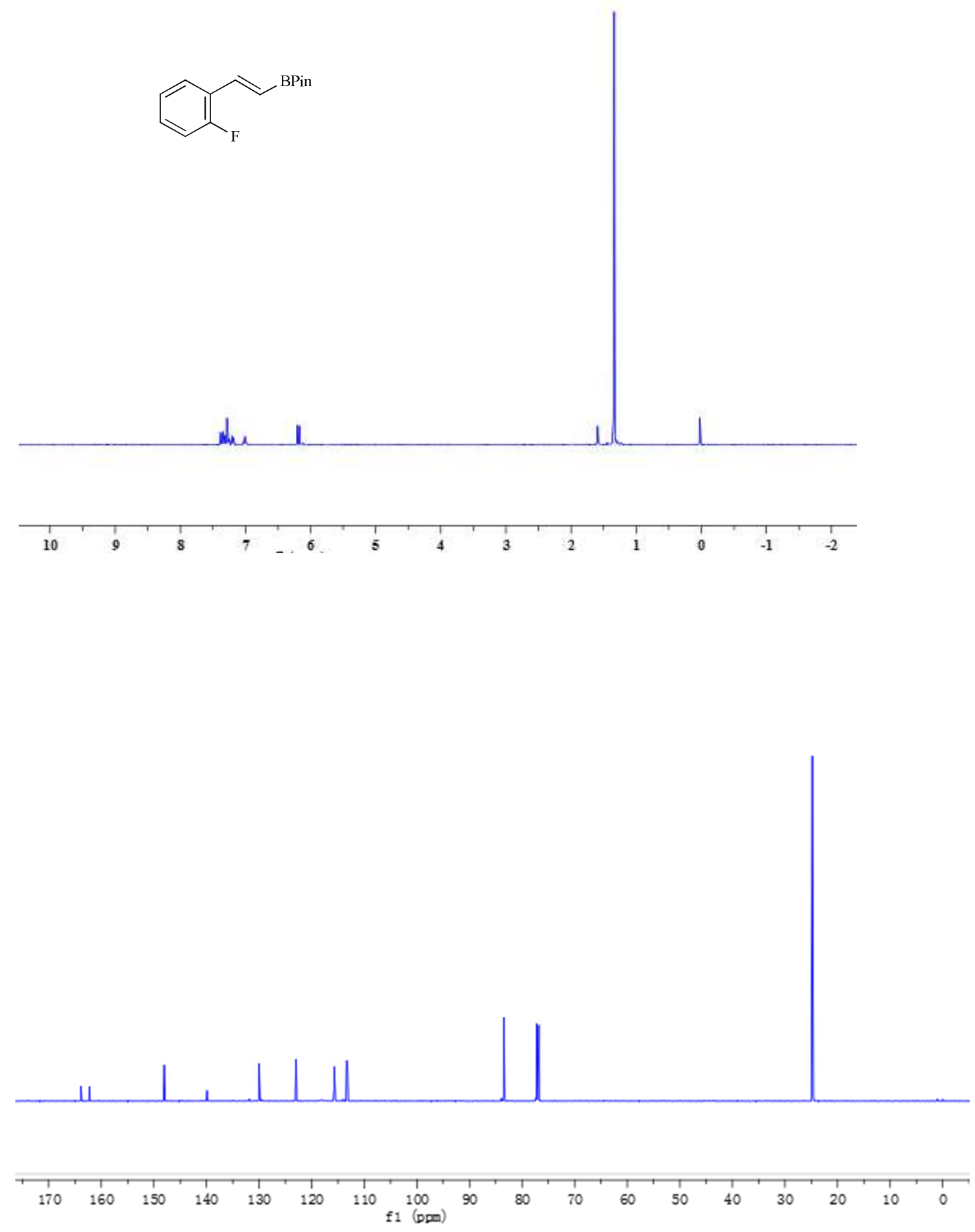

Scheme S9. ${ }^{1} \mathrm{H}$ (top) and ${ }^{13} \mathrm{C}$ NMR (bottom) $\left(\mathrm{CDCl}_{3}, 23{ }^{\circ} \mathrm{C}\right)$ of product 3 of Scheme 1. 

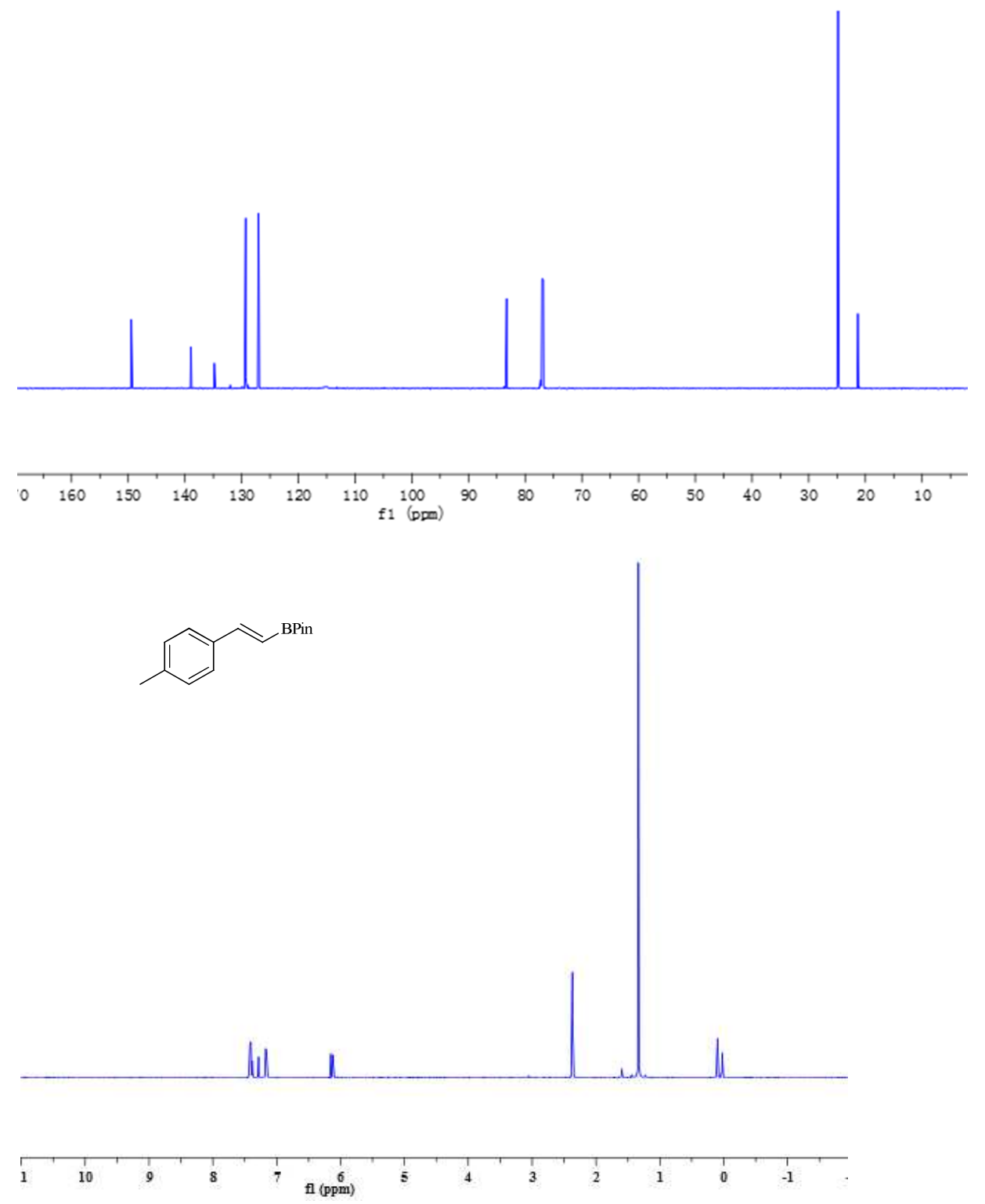

Scheme S10. ${ }^{1} \mathrm{H}$ ( top) and ${ }^{13} \mathrm{C}$ NMR (bottom) $\left(\mathrm{CDCl}_{3}, 23{ }^{\circ} \mathrm{C}\right)$ of product 4 of Scheme 1. 

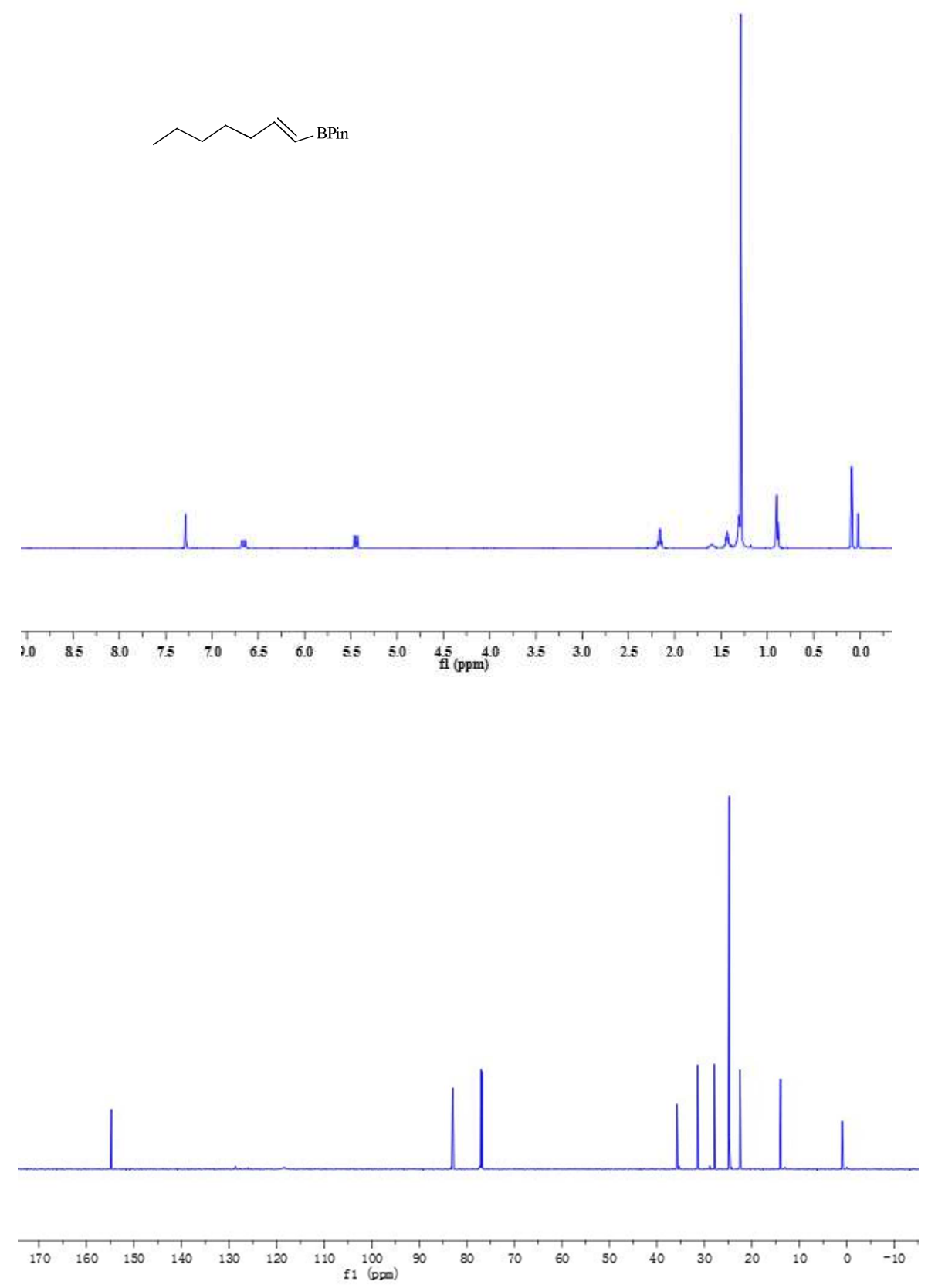

Scheme S11. ${ }^{1} \mathrm{H}$ ( top) and ${ }^{13} \mathrm{C}$ NMR (bottom) $\left(\mathrm{CDCl}_{3}, 23{ }^{\circ} \mathrm{C}\right)$ of product 7 of Scheme 1. 

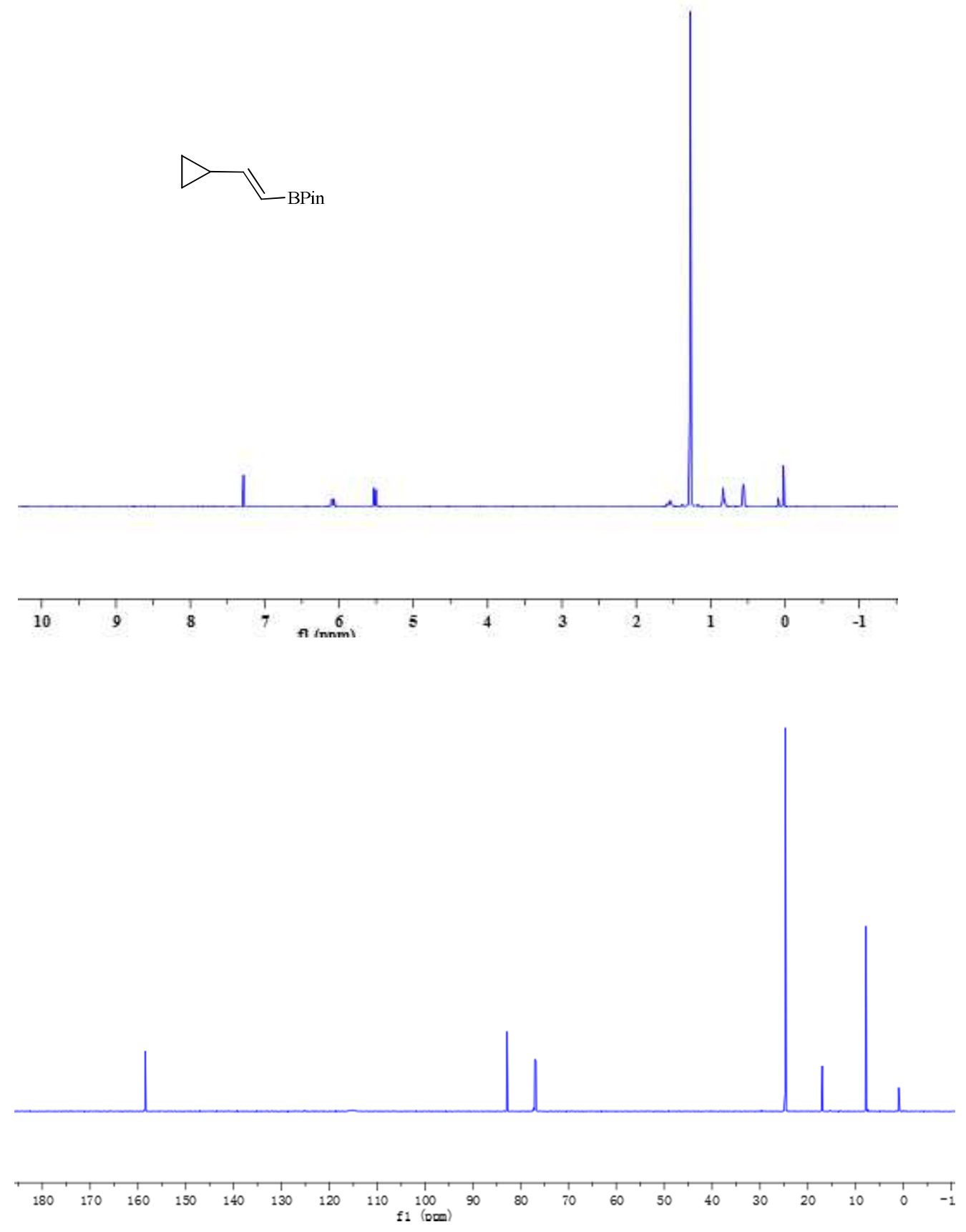

Scheme S12. ${ }^{1} \mathrm{H}$ (top) and ${ }^{13} \mathrm{C}$ NMR (bottom) $\left(\mathrm{CDCl}_{3}, 23{ }^{\circ} \mathrm{C}\right)$ of product 9 of Scheme 1. 


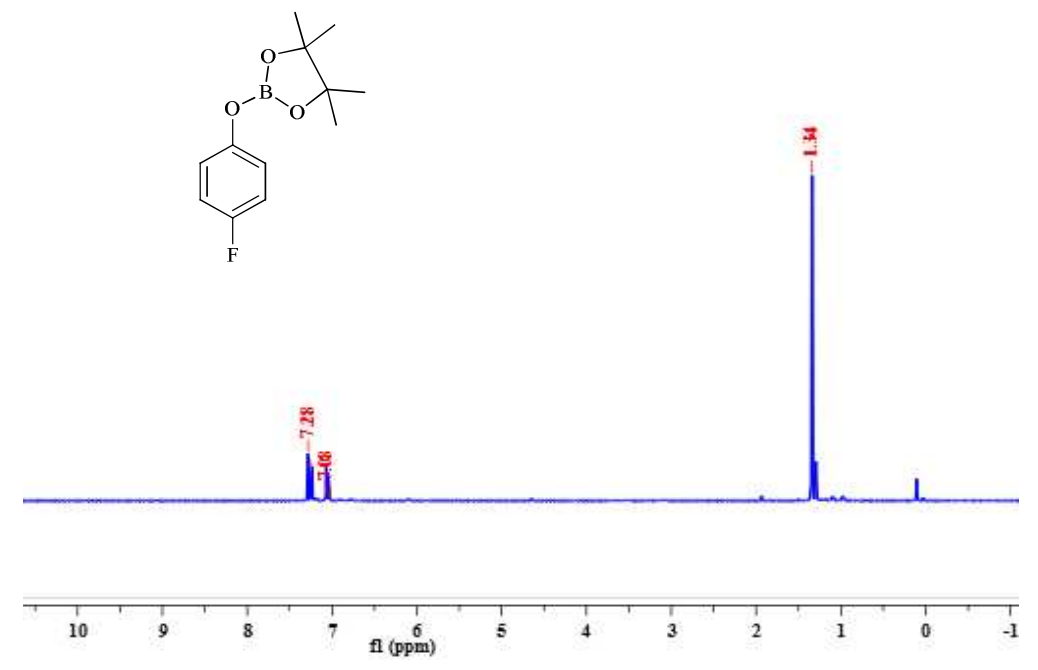

Scheme S13. ${ }^{1} \mathrm{H}$ NMR $\left(400 \mathrm{MHz}, \mathrm{CDCl}_{3}, 23^{\circ} \mathrm{C}\right)$ of product 1 of Scheme 3.
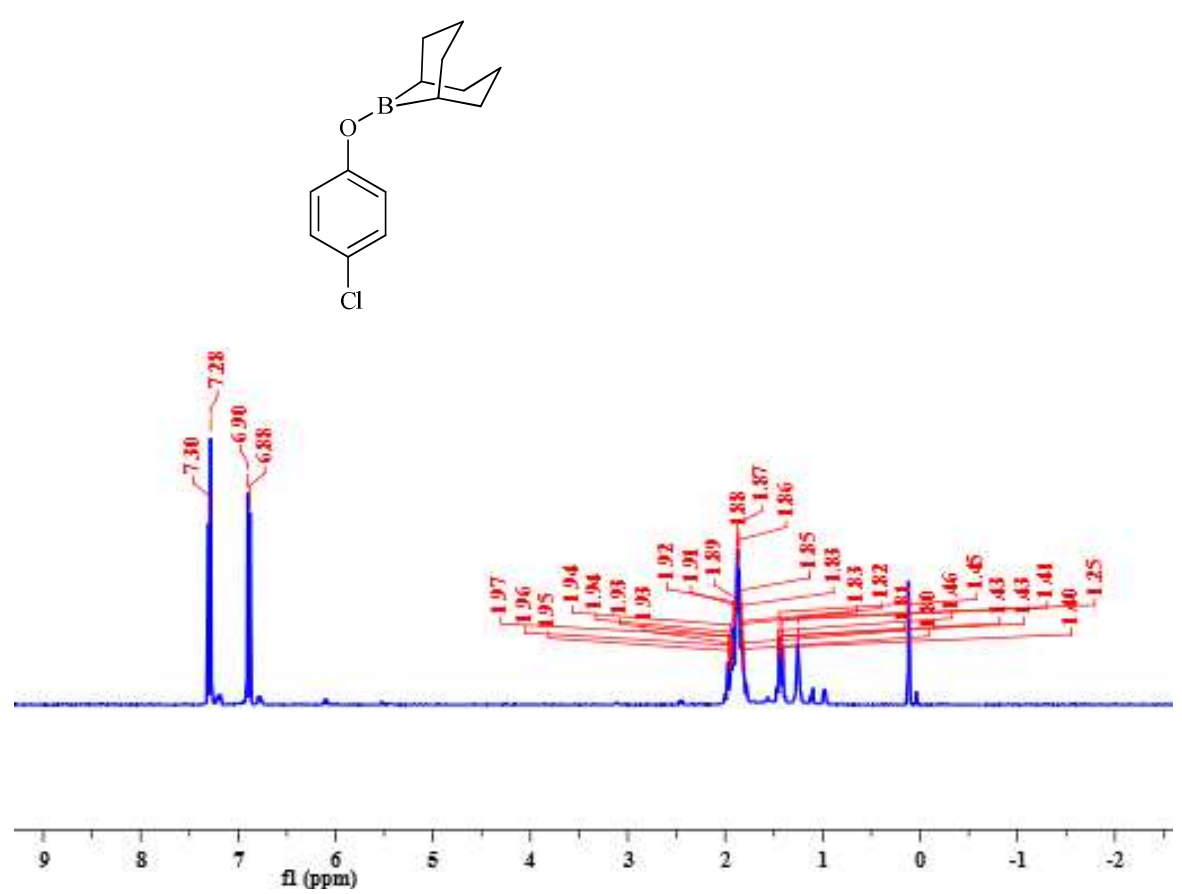

Scheme S14. ${ }^{1} \mathrm{H}$ NMR $\left(400 \mathrm{MHz}, \mathrm{CDCl}_{3}, 23^{\circ} \mathrm{C}\right)$ of product 4 of Scheme 3. 


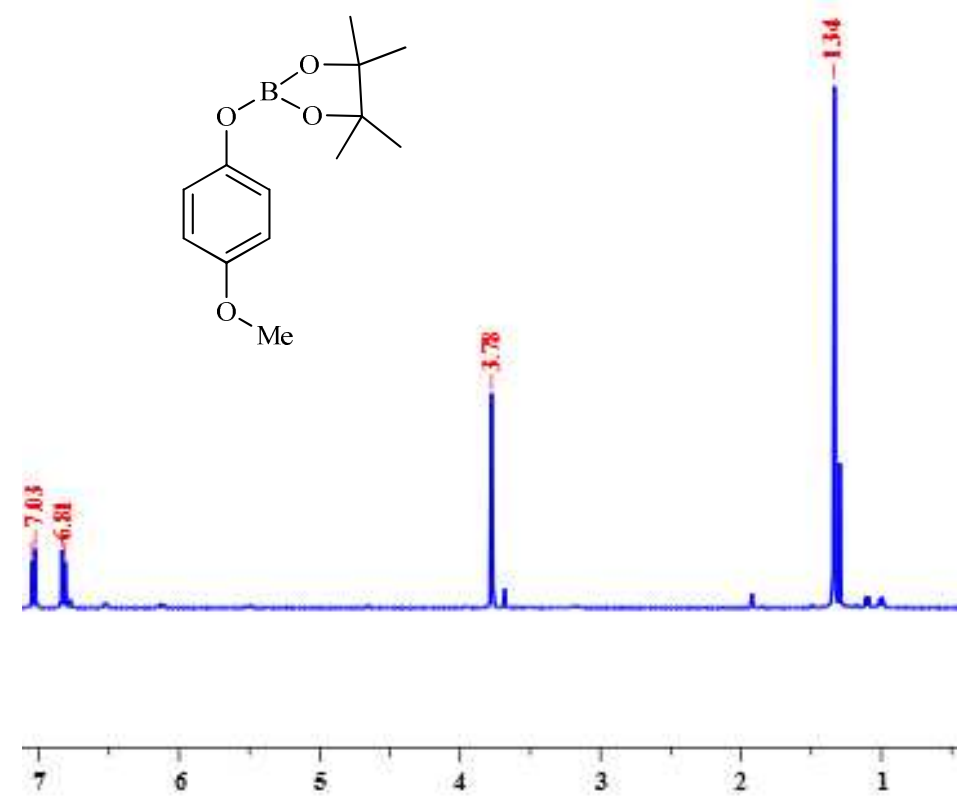

Scheme S15. ${ }^{1} \mathrm{H}$ NMR (400 MHz, $\left.\mathrm{CDCl}_{3}, 23{ }^{\circ} \mathrm{C}\right)$ of product 7 of Scheme 3.
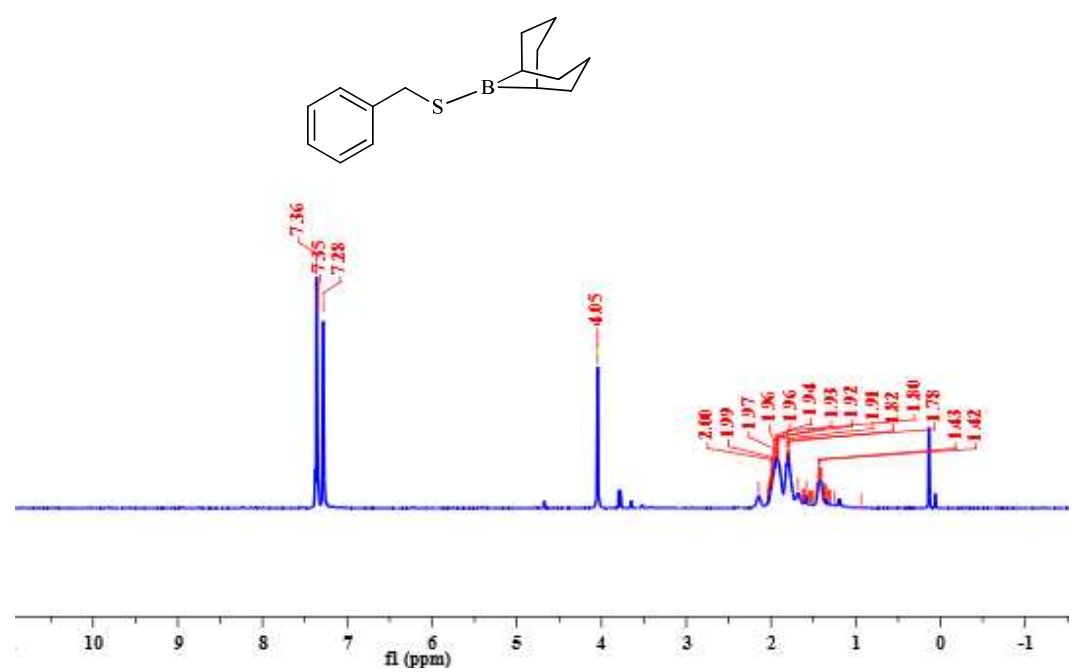

Scheme S16. ${ }^{1} \mathrm{H}$ NMR (400 MHz, $\left.\mathrm{CDCl}_{3}, 23{ }^{\circ} \mathrm{C}\right)$ of product 12 of Scheme 3. 


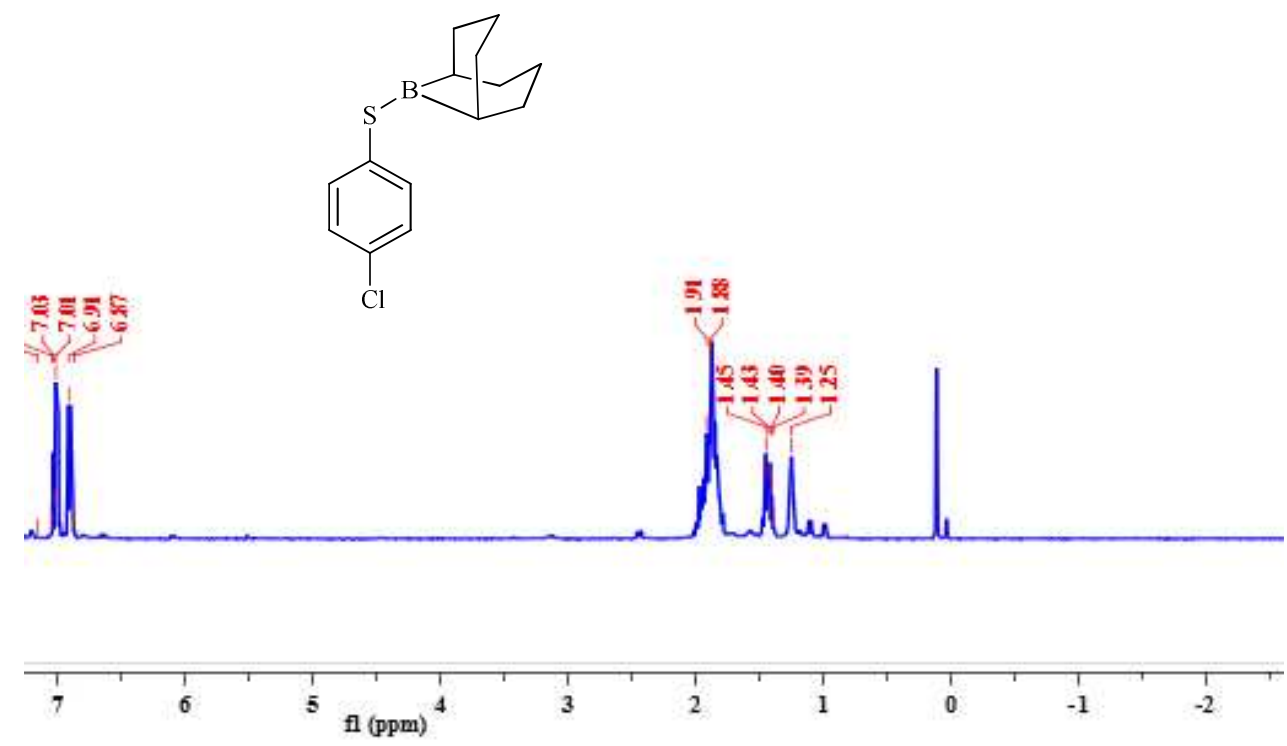

Scheme S17. ${ }^{1} \mathrm{H}$ NMR (400 MHz, $\left.\mathrm{CDCl}_{3}, 23{ }^{\circ} \mathrm{C}\right)$ of product 16 of Scheme 3.

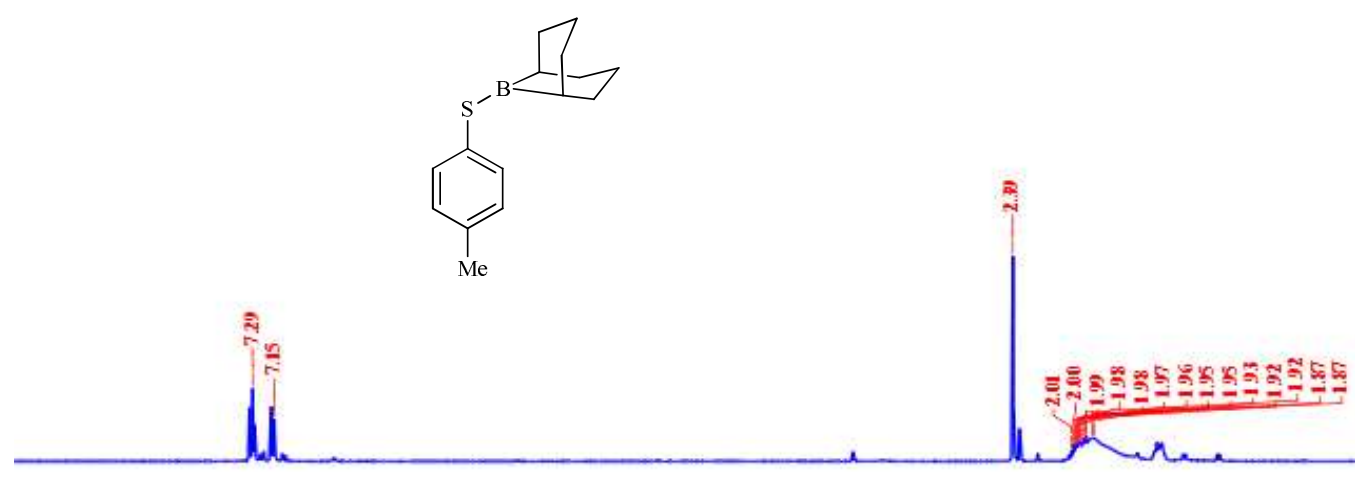

Scheme S18. ${ }^{1} \mathrm{H}$ NMR $\left(400 \mathrm{MHz}, \mathrm{CDCl}_{3}, 23^{\circ} \mathrm{C}\right)$ of product 18 of

Scheme 3. 

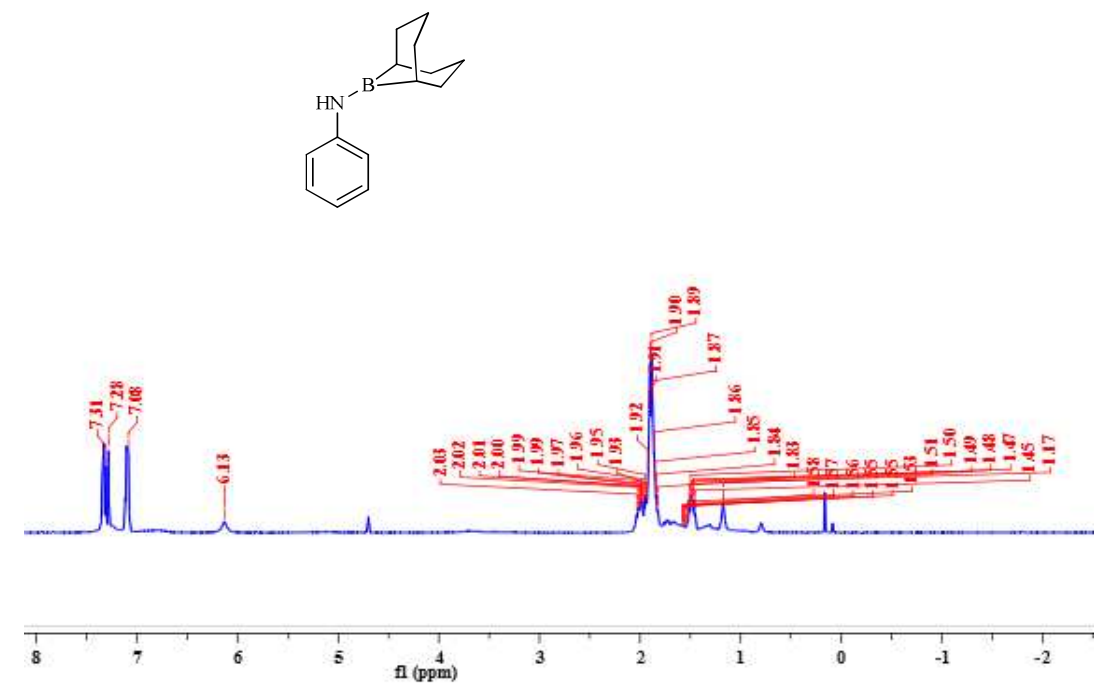

Scheme S19. ${ }^{1} \mathrm{H}$ NMR (400 MHz, $\left.\mathrm{CDCl}_{3}, 23{ }^{\circ} \mathrm{C}\right)$ of product 22 of

Scheme 3.

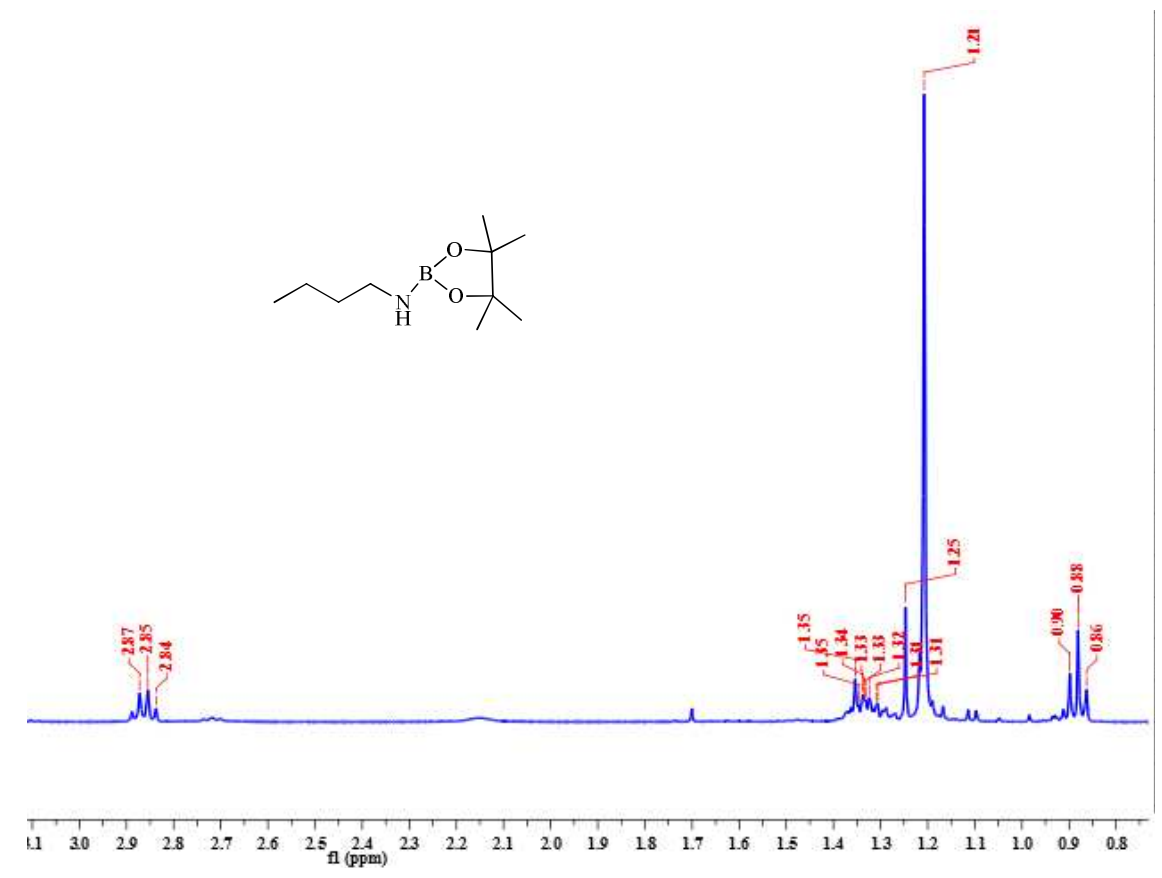

Scheme S20. ${ }^{1} \mathrm{H}$ NMR (400 MHz, $\left.\mathrm{CDCl}_{3}, 23{ }^{\circ} \mathrm{C}\right)$ of product 23 of

Scheme 3. 


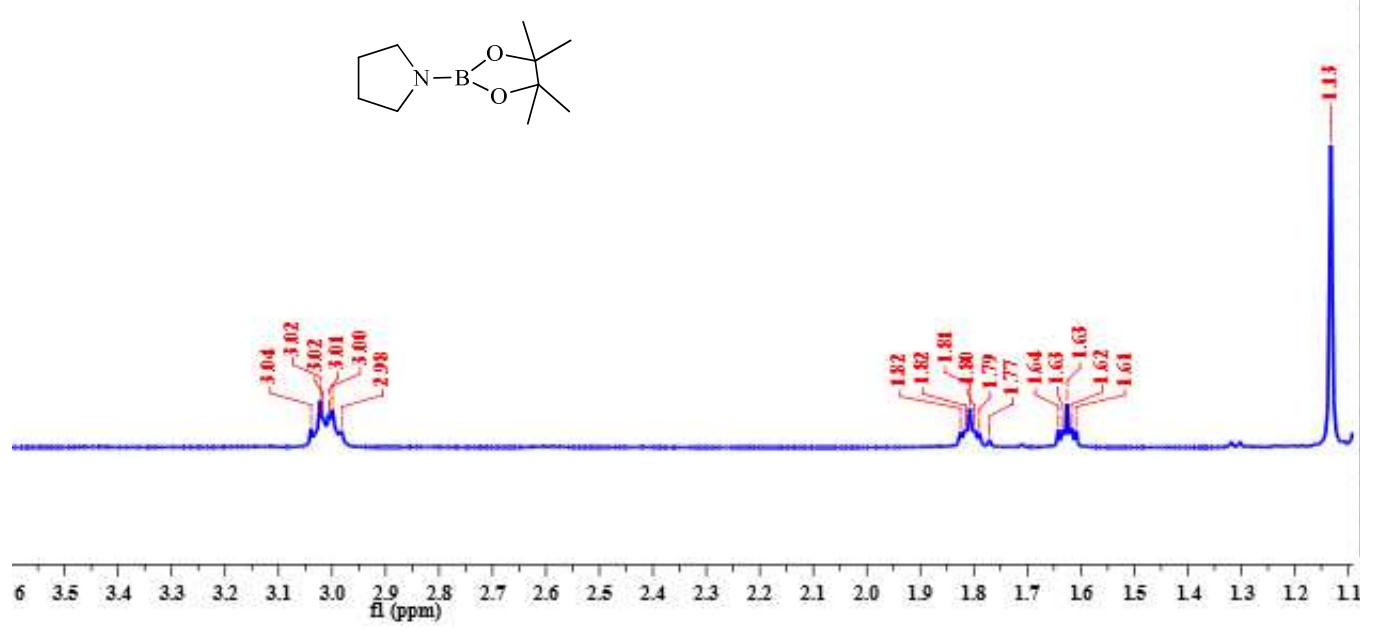

Scheme S21. ${ }^{1} \mathrm{H}$ NMR (400 MHz, $\left.\mathrm{CDCl}_{3}, 23{ }^{\circ} \mathrm{C}\right)$ of product 25 of Scheme 3.

\section{Computational Details}

The geometries of all the molecules were optimized gradient-corrected BP86 5 density functional with def2-SVP ${ }^{6}$ basis set using Gaussian 09 package. $^{7}$ The single point calculations of all optimized geometries were carried out with meta-GGA

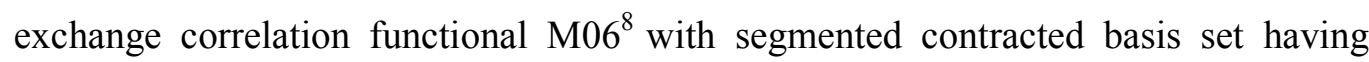
triple $\zeta$-quality augmented by two sets of polarization functions (def2-TZVPP). ${ }^{6}$ The energies calculated at the M06/def2-TZVPP level of theory were corrected by adding zero point energy at the BP8 6/def2-SVP level of theory. The free energies were calculated by adding electronic energy at the M06/def2-TZVPP level of theory and thermal correction to free energy at the BP86/def2-SVP level of theory at $298.15 \mathrm{~K}$ and $1 \mathrm{~atm}$. The Natural Bond Order $(\mathrm{NBO})^{9}$ and $\mathrm{MO}$ analysis were performed at theM06/def2-TZVPP//BP86/def2-SVP level of theory. The electrostatic potential map (ESP Plot) was also generated at the same level of theory. 
a)

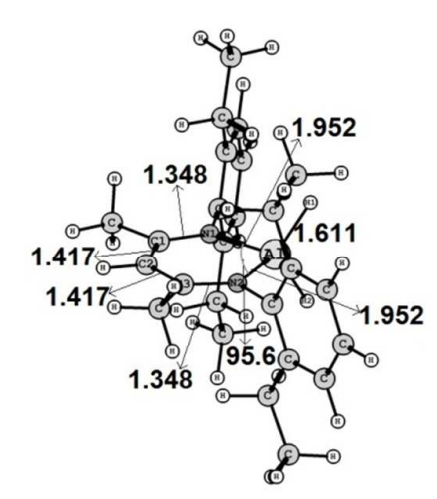

1

c)

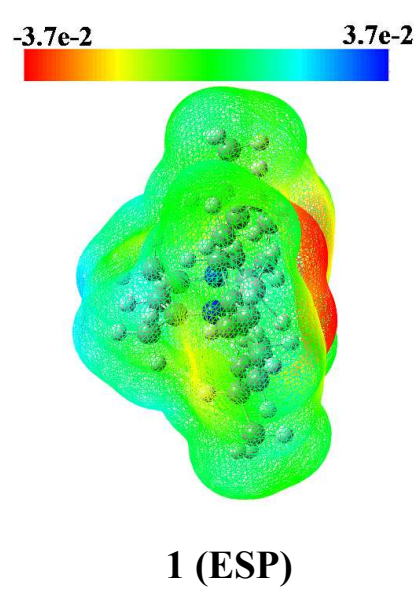

b)

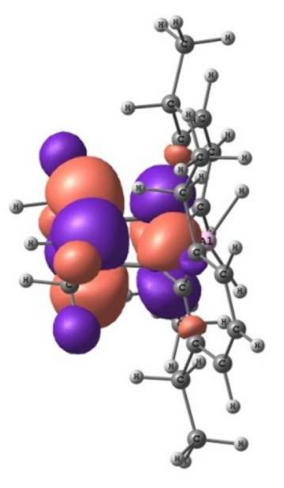

1-LUMO

$(-1.38 \mathrm{eV})$

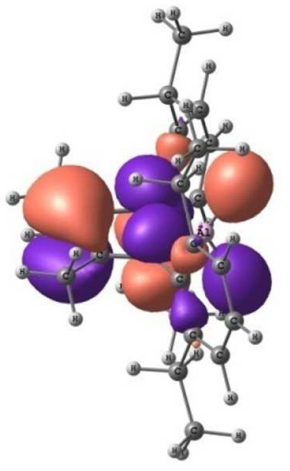

1-HOMO $(-6.11 \mathrm{eV})$

Figure S2: a) Optimized geometry, b) highest occupied molecular orbital (HOMO) and lowest unoccupied molecular orbital (LUMO) with their eigen values in $\mathrm{eV}$ in parenthesis and c) molecular ESP plot on the van der Waals surface of $\mathbf{L A l H}_{\mathbf{2}}$ (1, where $\left.\mathrm{L}=\mathrm{HC}(\mathrm{CMeNAr})_{2}, \quad \mathrm{Ar}=2,6-\mathrm{Et}_{2} \mathrm{C}_{6} \mathrm{H}_{3}\right)$ at the M06/Def2-TZVPP//BP86/Def2-SVP level of theory. 


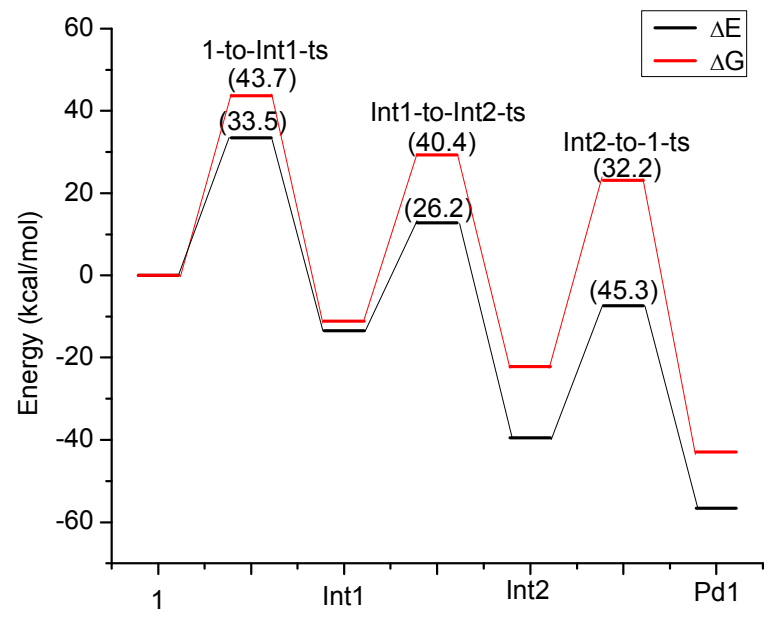

Figure S3: Reaction energy profile for the mechanism depicted in Scheme 2 for the catalytic hydroboration of phenyl acetylene by $\mathbf{L A l H}_{2}\left(\mathrm{~L}=\mathrm{HC}(\mathrm{CMeNAr})_{2}, \mathrm{Ar}=\right.$ 2,6- $\left.\mathrm{Et}_{2} \mathrm{C}_{6} \mathrm{H}_{3}\right) . \Delta \mathrm{E}$ and $\Delta \mathrm{E}^{\ddagger}$ represent the reaction energy and energy of activation. $\Delta \mathrm{G}$ and $\Delta \mathrm{G}^{\ddagger}$ represent the Gibbs free energy of the reaction and the free energy of activation.

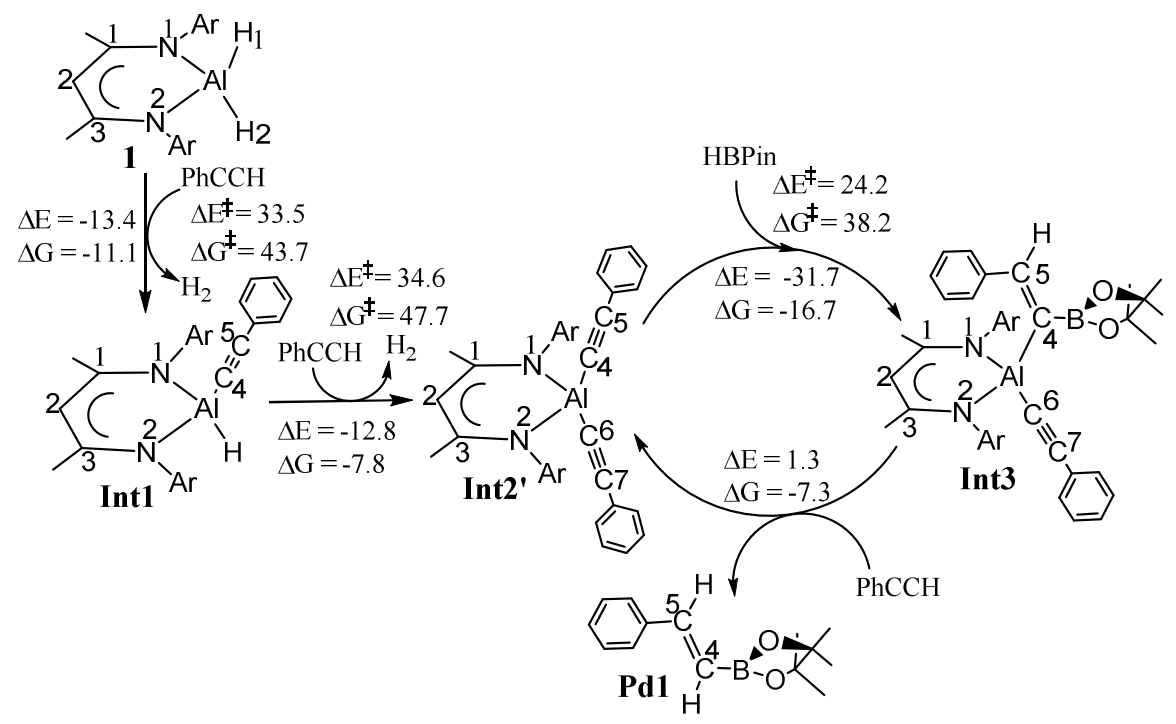

Scheme S22: Schematic representation of the mechanism of hydroboration of phenyl acetylene via. aluminum di-acetylide complex $\mathbf{L A l}(\mathbf{P h C C})_{2} \quad$ (Int2', L = $\left.\mathrm{HC}(\mathrm{CMeNAr})_{2}, \mathrm{Ar}=2,6-\mathrm{Et}_{2} \mathrm{C}_{6} \mathrm{H}_{3}\right) . \quad \Delta \mathrm{E}$ and $\Delta \mathrm{E}^{*}$ represent the reaction energy and energy of activation. $\Delta \mathrm{G}$ and $\Delta \mathrm{G}^{\star}$ represent the Gibbs free energy of reaction and free energy of activation. 


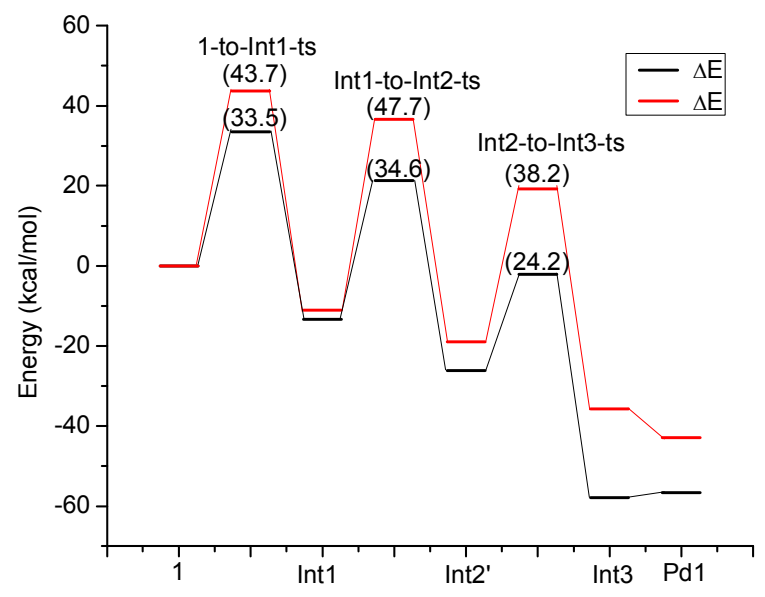

Figure S4: Reaction energy profile for the mechanism depicted in Scheme S22 for the catalytic hydroboration of phenyl acetylene by $\mathbf{L A l H}_{2} . \Delta \mathrm{E}$ and $\Delta \mathrm{E}^{*}$ represent the reaction energy and energy of activation. $\Delta \mathrm{G}$ and $\Delta \mathrm{G}^{\ddagger}$ represent the Gibbs free energy of the reaction and the free energy of activation.

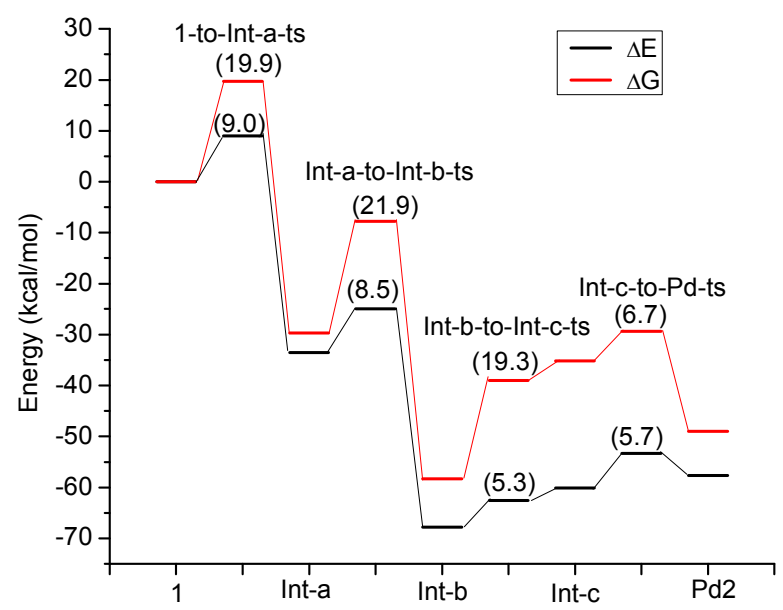

Figure S5: Reaction energy profile for the mechanism depicted in Scheme 4 for the dehydro-coupling of p-fluoro-phenol $\left(\mathrm{C}_{6} \mathbf{H}_{4} \mathbf{F O H}\right)$ with pinacolborane (HBPin) using $\mathbf{L A l H}_{2}$ as catalyst. $\Delta \mathrm{E}$ and $\Delta \mathrm{E}^{\ddagger}$ represent the reaction energy and energy of activation. $\Delta G$ and $\Delta G^{\ddagger}$ represent the Gibbs free energy of reaction and the free energy of activation. The transition state for the inter-conversion of Intb to Intc is slightly more stable than Intc. 


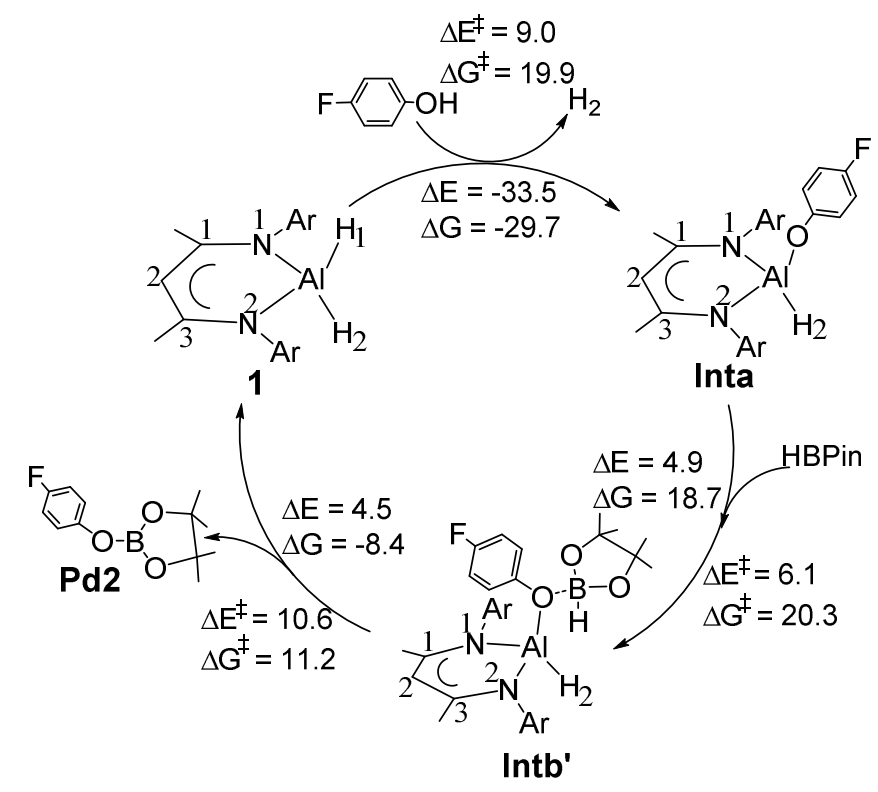

Scheme S23: Schematic representation of the mechanism of dehydro-coupling of p-fluro-phenol $\left(\mathrm{C}_{6} \mathbf{H}_{4} \mathbf{F O H}\right)$ with pinacolborane (HBPin), where one Al-H bond of $\mathbf{L A l H}_{2}$ is involved in the activation process. $\Delta \mathrm{E}$ and $\Delta \mathrm{E}^{\ddagger}$ represent the reaction energy and energy of activation. $\Delta \mathrm{G}$ and $\Delta \mathrm{G}^{\ddagger}$ represent the Gibbs free energy of the reaction and the free energy of activation.

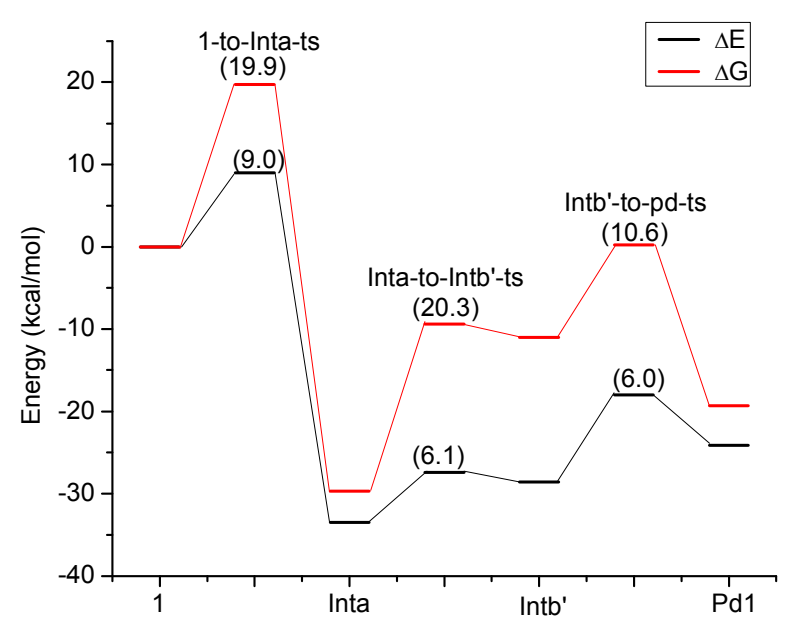

Figure S6: Reaction energy profile for the mechanism depicted in scheme S23 for the dehydro-coupling of $p$-fluro-phenol $\left(\mathrm{C}_{6} \mathbf{H}_{4} \mathbf{F O H}\right)$ with pinacolborane (HBPin) using $\mathbf{L A l H}_{2}$ as catalyst. $\Delta \mathrm{E}$ and $\Delta \mathrm{E}^{\ddagger}$ represent the reaction energy and energy of activation. $\Delta \mathrm{G}$ and $\Delta \mathrm{G}^{\ddagger}$ represent the Gibbs free energy of the reaction and the free energy of activation. 


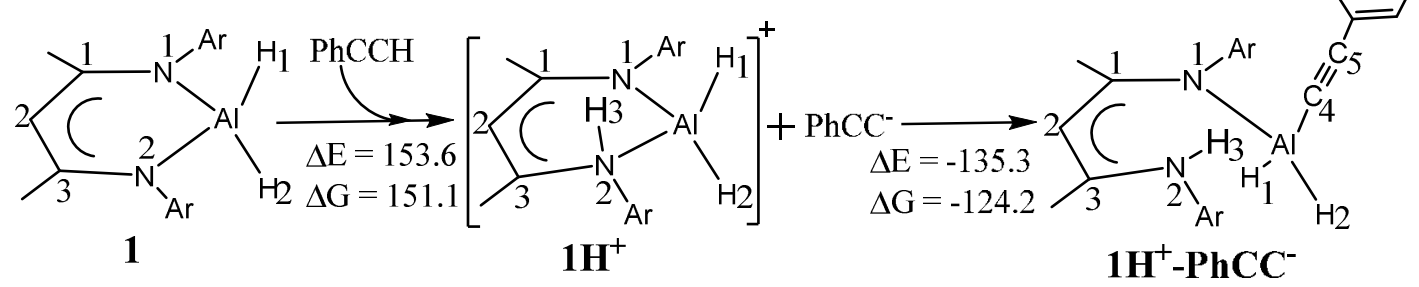

Scheme S24: Schematic representation of the initial steps for the activation of phenyl acetylene by metal-ligand cooperation, where both the metal and one nitrogen atom of beta-diketiminate ligand are involved for the activation process. $\Delta \mathrm{E}$ and $\Delta \mathrm{G}$ represent the reaction energy and Gibbs free energy of reaction at the M06/def2-TZVPP//BP86/def2-SVP level of theory.

Table S2: The NBO charge on the selected atoms of $\mathbf{L A l H} \mathbf{2}(\mathbf{1})$ and the intermediates of hydroboration reaction at the M06/Def2-TZVPP//BP86/Def2-SVP level of theory.

\begin{tabular}{cccccc}
\hline Atom & $\mathbf{1}$ & Int1 & Int2 & Int3 & Int2' \\
\hline A1 & 1.40 & 1.59 & 1.65 & 1.87 & 1.79 \\
C1 & 0.36 & 0.37 & 0.36 & 0.36 & 0.37 \\
C3 & -0.44 & -0.44 & -0.45 & -0.45 & -0.44 \\
C4 & 0.36 & -0.37 & 0.37 & 0.37 & 0.37 \\
C5 & -- & -0.54 & -0.89 & -0.91 & -0.54 \\
C6 & -- & -0.04 & -0.14 & -0.14 & -0.04 \\
C7 & -- & -- & -- & -0.56 & -0.55 \\
N1 & -0.74 & -0.75 & -0.76 & -0.78 & -0.76 \\
N2 & -0.74 & -0.75 & -0.76 & -0.78 & -0.76 \\
H1 & -0.41 & -0.40 & -- & -- & -- \\
H2 & -0.41 & -- & -0.43 & -- & -- \\
B & -- & -- & 1.12 & 1.15 & 1.15 \\
\hline
\end{tabular}


Table S3: The NBO charge on the selected atoms of $\mathbf{L A l H}$ and the intermediates of the dehydro-coupling reaction at the M06/Def2-TZVPP//BP86/Def2-SVP level of theory.

\begin{tabular}{cccccc}
\hline Atom & $\mathbf{1}$ & Inta & Intb & Intc & Intb' \\
\hline Al & 1.40 & 1.80 & 2.19 & 2.13 & 1.74 \\
C1 & 0.36 & 0.37 & 0.37 & 0.37 & 0.37 \\
C2 & -0.44 & -0.43 & -0.43 & -0.45 & -0.44 \\
C3 & 0.36 & 0.37 & 0.37 & 0.37 & 0.37 \\
O1 & -- & -0.93 & -0.96 & -0.84 & -0.83 \\
O2 & -- & -- & -0.96 & -0.96 & -- \\
N1 & -0.74 & -0.77 & -0.81 & -0.81 & -0.78 \\
N2 & -0.74 & -0.77 & -0.81 & -0.80 & -0.77 \\
H1 & -0.41 & & -- & -- & \\
H2 & -0.41 & -0.43 & -- & -- & -0.42 \\
F1 & -- & -0.33 & -0.33 & -0.32 & -0.32 \\
F2 & -- & -- & -0.33 & -0.33 & \\
B & -- & -- & -- & 0.97 & 0.95 \\
\hline
\end{tabular}




\section{References}

1. Zhou, B.; Chen, H.; Wang, C. J. Am. Chem. Soc. 2009, 135, 1264.

2. Sheldrick, G. M. SADABS, Empirical Absorption Correction Program, University of Göttingen, Göttingen, Germany, 1997.

3. Sheldrick, G. M. SHELXS-90, Program for Structure Solution.ActaCrystallogr. Sect. A.1990, 46, 467-473.

4. Sheldrick, G. M. SHELXL-97, Program for Crystal Structure Refinement; University of Göttingen, Germany, 1997.

5. (a) Becke, A. D. Phys. Rev. A 1988, 38, 3098-3100; (b) Perdew, J. P. Phys. Rev. B 1986, 33, 8822-8824.

6. (a) Andrae, D.; Häußermann, U.; Dolg, M.; Stoll, H.; Preuß, H.Theor. Chim. Acta, 1990, 77, 123-141. (b) Metz, B.; Stoll, H.; Dolg, M. J.Chem. Phys., 2000, 113, 2563-2569. (c) Peterson, K. A.; Figgen, D.; Goll, E.; Stoll, H.; Dolg, M.J. Chem. Phys., 2003, 119, 11113-11123. (d) Leininger, T.; Nicklass, A.; Kuechle, W.; Stoll, H.; Dolg, M.; Bergner, A.Chem. Phys. Lett., 1996, 255, 274-280. (e) Kaupp, M.; Schleyer, P.V.; Stoll, H.; Preuss, H.J. Chem. Phys., 1991, 94, 1360-1366.

7. (a) Frisch, M. J.; Trucks, G. W.; Schlegel, H. B.; Scuseria, G. E.; Robb, M. A.; Cheeseman, J. R.; Scalmani, G.; Barone, V.; Mennucci, B.;Petersson, G. A.; Nakatsuji, H.; Caricato, M.; Li, X.; Hratchian, H. P.; Izmaylov, A. F.; Bloino, J.; Zheng, G.; Sonnenberg, J. L.; Hada, M.;Ehara, M.; Toyota, K.; Fukuda, R.; Hasegawa, J.; Ishida, M.; Nakajima, T.; Honda, Y.; Kitao, O.; Nakai, H.; Vreven, T.; Montgomery, J. A. Jr.;Peralta, J. E.; Ogliaro, F.; Bearpark, M.; Heyd, J. J.; Brothers, E.; Kudin, K. N.; Staroverov, V. N.; Keith, T.; Kobayashi, R.; Normand, J.;Raghavachari, K.; Rendell, A.; Burant, J. C.; Iyengar, S. S.; Tomasi, J.; Cossi, M.; Rega, N.; Millam, J. M.; Klene, M.; Knox, J. E.; Cross, J. B.;Bakken, V.; Adamo, C.; Jaramillo, J.; Gomperts, R.; Stratmann, R. E.; Yazyev, O.; Austin, A. J.; Cammi, R.;

Pomelli, C.; Ochterski, J. W.;Martin, R. L.; Morokuma, K.; Zakrzewski, V. G.; Voth, G. A.; Salvador, P.; Dannenberg, J. J.; Dapprich, S.; Daniels, A. D.; Farkas, 
O.;Foresman, J. B.; Ortiz, J. V.; Cioslowski, J.; Fox, D. J.; Gaussian, Inc., Wallingford CT, 2010.

8. Zhao, Y.; Truhlar, D. G. Theor. Chem. Acc. 2008, 120, 215-241.

9. (a) Reed, A. E.; Curtiss, L. A.; Weinhold, F. Chem. Rev. 1988, 88, 899-926. (b) NBO 6.0. Glendening, E. D.;Badenhoop, J. K.; Reed, A. E.; Carpenter, J. E.; Bohmann, J. A.; Morales, C. M.; Landis, C. R.; Weinhold F. (Theoretical Chemistry Institute, University of Wisconsin, Madison, WI, 2013); http://nbo6.chem.wisc.edu/. 